\title{
Los efectos de la nulidad de los planes urbanísticos en Andalucía y su repercusión en las edificaciones ilegales
}

\author{
Venancio Gutiérrez Colomina \\ Secretario General del Ayuntamiento de Málaga y Profesor Asociado \\ de Derecho Administrativo de la Universidad de Málaga. (Profesor Titular \\ Acreditado por la ANECA)
}

I. LA EVOLUGIÓN LEGISLATIVA EN MATERIA DE ORDENAGIÓN DEL TERRITORIO, URBANISMO Y LEGISLACIÓN SEGTORIAL. 1. LEGISLACIÓN URBANÍSTICA.- 1.1.- Proceso invertido. 1.2.- La Planificación de la Ordenación del Territorio. 1.3.- Las modificaciones de la LOUA para su adaptación al TRLS08. 1.4.- Regulación de edificaciones ilegales en el SNU. II.- LA DOGTRINA JURISPRUDENGIAL RELEVANTE ACERCA DE LA NULIDAD DE LOS PLANES GENERALES POR APLICACIÓN DEL DERECHO URBANISTICO DE ANDALUCIA. 1.-IDEAS GENERALES. 2.- MOTIVOS NULIDAD. 2.1- Limitación del PGOU y de la Planificación de Ordenación del Territorio por el Régimen del Suelo. A).- Carácter reglado del Suelo Urbano.- B) La naturaleza reglada del SNU de especial protección.- 2.2.- Análisis de la jurisprudencia que ha originado la nulidad del planeamiento territorial y urbanístico por incidir en el carácter reglado del Suelo Urbano y del SNUEP.- A) PGOU de Marbella.- B) Mantenimiento del carácter reglado en servidumbre de protección de la ZMT C) Nulidad de planeamiento por no respeto del carácter de reglado del Suelo No Urbanizable de especial protección. 2.3.- Motivos nulidad: no corresponde al plan modular. La legalización de lo ilegalmente construido. la potestad de ejecutar las sentencias corresponde exclusivamente al poder judicial. 2.4.-Motivos nulidad: no procede exigir nuevas prestaciones que alteren el equilibrio del derecho de propiedad y que sean dependiente de la modulación de la legalización realizada por el planificador.2.5.- Motivos nulidad: no cabe proceder a la alteración por el planificador de mecanismos legales de la responsabilidad por incumplimiento deberes urbanísticos 2.6.- Otros motivos nulidad pla- 
neamiento urbanístico y ordenación territorial por legislación territorial A) La evaluación ambiental estratégica (EAE) no cumple con la Directiva 2001/42/ce ni con Ley 9/2006 y no contiene evaluación de alternativas razonables aunque sea respetuoso con decreto autonómico 292/95 (STS 2180/2014 de 27 de octubre de 2014 FJ 12 y 13). B) Ausencia del informe de sostenibilidad económica del art. 15.4 del TRLS08 (STS 2180/2014 de 27 de octubre de 2014 FJ 15).- G) Ausencia informe evaluación de impacto por razón de género (STS 6-X-2015: nulidad POT Costa Sol Occidental). D) No haber recabado el informe sectorial de telecomunicaciones. (Plan General de Laredo). III.-ALGANGE Y EFEGTOS NULIDAD. PROPUESTAS DE SOLUCIÓN DE LOS EFEGTOS DE LA NULIDAD.- 1.-EFECTOS DE LA NULIDAD DE LOS PLANES URBANÍSTICOS. 1.1.-Punto de partida: naturaleza jurídica de Disposición General.- 1.2.-Efectos. A) En el Planeamiento y Gestión. B) En las licencias. 2.-PROPUESTAS PARA MITIGAR LAS CONSEGUENGIAS Y EFEGTOS DE LA NULIDAD DEL PLANEAMIENTO URBANISTICO Y ORDENAGIÓN DEL TERRITORIO EN ANDALUGIA. 2.1.- Medidas en relación con el Planeamiento. A) Adaptación Parcial Planeamiento vigente a la a la entrada en vigor de la LOUA de acuerdo con el Decreto 11/2008, de 22 de Enero. B) Subsiguientes modificaciones. G) Revisión parcial o general. 2.2.-Medidas en relación las licencias ilegales. A) Sin procedimiento judicial: sólo administrativo. B) Con procedimiento judicial firme.

RESUMEN: El procedimiento de aprobación de los Planes Generales de Ordenación Urbanística es complejo, laborioso y largo. Deben de incorporarse una serie de informes sectoriales que suelen ser preceptivos. El carácter de norma jurídica que tienen los Planes Urbanísticos y Territoriales origina, que cualquier vicio jurídico que tenga su procedimiento de aprobación, provoque la nulidad de pleno derecho. La nulidad de un PGOU produce unos efectos impactantes en la situación socioeconómica del municipio al que afecta y una gran repercusión en la situación de las edificaciones ilegales.

Este artículo, tomando como marco Andalucía, hace un repaso por su legislación urbanística y sectorial, analizando las causas que han provocado la nulidad del planeamiento en la doctrina jurisprudencial reciente, su alcance y los efectos de la nulidad en el Planeamiento, Gestión y licencias de edificaciones. Finalmente se estudian las posibles soluciones para mitigar las consecuencias de la nulidad de los Planes de Urbanismo y Ordenación del Territorio. 
PALABRAS CLAVE: Plan Norma Jurídica. Legislación Sectorial. Suelo Reglado Urbano y No Urbanizable de Especial Protección. Igualdad de Género. Imposibilidad legal o material. Adaptación Planeamiento.

ABSTRACT: The approval procedure of the General Plans of Urban Planning is complex, laborious and lengthy. They must incorporate a series of sectoral reports which are often mandatory. The normative character of Urban and Territorial Plans has as a consequence that any legal defect of its approval procedure can cause their nullity. The invalidity of a General Plan of Urban Planning produces harmful effects on the socio-economic situation of the municipality and it has a significant impact on the situation of illegal buildings.

This paper, taking Andalusia's legal framework as a reference, reviews its urban and sectoral legislation, analyzes the causes that have led to the annulment of its planning in recent case law and the extend to which that annulment affects the Planning, Management and Licensing of buildings. Eventually the paper is focused on possible solutions to mitigate the consequences of Plans of Urban and Regional Planning invalidity.

KEYWORDS: Standard Regulation Urban Plan. Sectoral legislation. Ruled Urban Soil and Non-constructible Special Protection. Gender equality. legal or material imposibility. Adaptation Planning.

\section{LA EVOLUGIÓN LEGISLATIVA EN MATERIA DE ORDENA- CIÓN DEL TERRITORIO, URBANISMO Y LEGISLACIÓN SECTORIAL}

\section{Legislación urbanística}

1.1.- Proceso invertido.- La legislación territorial y Urbanística de Andalucía ha seguido un proceso legislativo inverso a otras Comunidades Autónomas, recorriendo el camino al revés, empezando, como vulgarmente se dice, «la casa por el tejado». Andalucía fue una de las últimas Comunidades Autónomas en elaborar una Ley de Ordenación del Territorio: La Ley de Ordenación del Territorio no se aprobó hasta enero de 1994. En un orden racional, debía haber sido la primera en aprobarse y, a continuación, se debía haber dictado una legislación urbanística engarzada con ella y posteriormente, una legislación sectorial imbricada en las dos anteriores. 
No ha sido así, sino que se fue a la última fase directamente; es decir, se aprobó previamente a la Ley de Ordenación Urbanística de Andalucía, una parte importante de la legislación sectorial ${ }^{1}$.

La LOUA en su art. 32, en un intento de remediar esta situación, estableció una cierta homogeneidad a la hora de emitir estos informes sectoriales y así señala que la aprobación inicial del instrumento del planeamiento obligará al requerimiento de los informes, dictámenes u otro tipo de pronunciamientos de los órganos y entidades administrativas gestores de intereses públicos afectados, previstos legalmente como preceptivos, que deberán ser emitidos en esta fase de tramitación del instrumento de planeamiento y en los plazos que establezca su regulación específica. La modificación de la LOUA a través de Ley 2/2012 estableció la creación de un órgano colegiado representativo de los distintos órganos y entidades administrativas para mejorar la tramitación de estos informes sectoriales. Mediante el Decreto 36/2014, de 11 de febrero se crearon las Comisiones Provinciales de Coordinación Urbanística que tienen como objetivo tanto, integrar y armonizar la emisión de los informes preceptivos que debe emitir la Junta de Andalucía a la tramitación del planeamiento urbanístico, como facilitar las tareas de colaboración y cooperación con los municipios.

La falta de coherencia y coordinación que originó este proceso, en su día, se intentó solucionar a posteriori con la aprobación de la Ley 1/1994, de 11 de enero de ordenación del Territorio de Andalucía, (LOTA). Sin embargo, este proceso de creación legislativa invertida dio lugar a que la planificación sectorial y urbanística haya carecido de coherencia e ilación, al no tratamiento de los problemas urbanísticos de Andalucía de manera integral y coordinada, así como que la Planificación de la Ordenación del Territorio que se ha ido aprobando, haya producido diversos problemas en la planificación sectorial y urbanística en vigor.

Por otra parte, la STC de 20 de marzo de 1997, publicada el 25 de abril de 1997, que derogó en gran parte el TR/1992, acentuando la desestatización del derecho urbanístico, como consecuencia de la reducción del papel que ha de jugar la legislación supletoria del Estado, vino a irrumpir inesperadamente en este panorama,

\footnotetext{
Ley 8/1988, de 2 de noviembre, de Puertos Deportivos en Andalucía (Derogada), Ley 2/1989, de julio de 1991 Patrimonio Histórico de Andalucía (Derogada), Ley 2/1992 de Ordenación Forestal de Andalucía, Ley 7/1994, de 18 de marzo de protección ambiental (Derogada). Ley 5/1999, de Prevención y lucha contra los incendios Forestales (Derogada), Ley 1/1996 de 10 de Enero del Comercio Interior, Ley 5/1999, (Derogada por Decreto Legislativo 1/2012), de Prevención y lucha contra los incendios Forestales Ley 12/1999, de 15 de Diciembre de Turismo, Ley 13/1999, de 15 de Diciembre, de Espectáculos Públicos y Actividades Recreativas y Ley 8/2001, de 12 de julio de Carreteras, entre otras.
} 
actuando como el elemento dinamizador necesario para sacudir la sequía legislativa en materia urbanística de la Junta de Andalucía.

La primera consecuencia que produjo la Sentencia en nuestra Comunidad Autónoma, fue la de reponer como normativa autonómica la legislación estatal supletoria que había derogado el Tribunal Constitucional por razones competenciales. Pero era obvio que Andalucía no podía seguir más tiempo sin que se pusiera en marcha una legislación urbanística que contemplara la especial singularidad de la ordenación y gestión territorial andaluza, aunque, ésta no se aprobó, hasta el mes de diciembre de 2002.

La LOUA supuso, por fin, la instauración de un marco legal propio en nuestra CA que debía haber sido completado a través de un adecuado desarrollo reglamentario que diese contenido a una serie de conceptos jurídicos indeterminados que contenía la ley, y evitase los conflictos de interpretación entre la Junta y los Ayuntamientos ${ }^{2}$. Sin embargo el desarrollo reglamentario no se ha producido, salvo el Reglamento de Disciplina Urbanística de Andalucía (aprobado por Decreto 6/2010, de 16 de marzo), ni tiene visos de producirse y el sistema urbanístico andaluz no se ha ido completando como hubiera sido de desear y además a partir de la aprobación de la LOUA, se ha producido un desarrollo de la legislación territorial y urbanística que ha ido estableciendo una progresiva reducción de la autonomía municipal.

Así, el art. 43 de la Ley 3/2004 de 28 de diciembre introdujo en la LOTA la regulación de las Actuaciones de interés Autonómico, para las que no se necesitaba ni licencia, ni en general, acto preventivo de control municipal, bastando una mera audiencia al Municipio afectado.

Posteriormente, se aprobó una modificación de la LOUA por la Ley 13/2005 de 11 de Noviembre de Medidas para la Vivienda Protegida y el Suelo (LVPS), que entre otras cosas, preveía la posibilidad de atribuir a la Junta de Andalucía la potestad de planeamiento, que corresponda a los municipios, en los casos de grave incumplimiento en el ejercicio de competencias urbanísticas que impliquen una manifiesta afectación a la ordenación del territorio y urbanismo. A tal efecto, se añadió un polémico aptd 4 al art. 31 de la LOUA, en el que se regulaba la competencia para la formulación y aprobación de los instrumentos de planeamiento, posibilitando que en casos de grave incumplimiento por los municipios en el ejercicio de competencias urbanísticas que implicasen una manifiesta afectación a la ordenación del territorio

\footnotetext{
2 Entre los conceptos jurídicos indeterminados de la LOUA destacan entre otros: los de "proceso inadecuado urbano" (art. 9.B), "necesidad justificada de vivienda" \{art. 52.1 B)a)\}, "utilidad pública o interés social" \{art. 42.5 C)a)\}, "aprovechamiento objetivo considerablemente superior al existente" \{art. 45.2 B)b)\}, "mayor beneficio colectividad" (art. $1191^{\mathrm{a}}$ ).
} 
y urbanismo competencia de la CAA, podría atribuirse la potestad de planeamiento de los municipios, a la Consejería competente, por acuerdo del Consejo de Gobierno con audiencia al municipio, dictamen del Consejo Consultivo y previo informe favorable del Parlamento. En mi opinión ${ }^{3}$, cabía afirmar la inconstitucionalidad del art. 31.4 de la LOUA que iba más allá de lo preceptuado en el art. 60 LRBRL, sin que existiera razón suficiente. La STG de 9 de julio de 2015 lo ha declarado nulo porque "el precepto contradice el art. 60 LBRL, que no permite una sustitución general en materia de planeamiento urbanístico." En relación con la disciplina urbanística, modificó el art. 188 que regulaba las competencias de la G.A. en materia de protección de ordenación urbanística, reduciendo de un mes a 10 días, el plazo desde el requerimiento al Alcalde sin que éste adoptase medidas cautelares, para que las adoptara la Junta. También como alertábamos ${ }^{4}$ la reducción del plazo del requerimiento incumplía el plazo mínimo de un mes, establecido como regla general en el art. 60 de la LRBRL, y por ello el TC, en la misma Sentencia anterior, declaró inconstitucional y nulo el art. 188 de la LOUA.

1.2. La Planificación de la Ordenación del Territorio.- A partir de la aprobación de la LOTA. se fueron poniendo en marcha de manera desigual los Planes Subregionales de Ordenación del Territorio (POTS). Por otra parte el de Cádiz, fue anulado por el TSJA, con sede en Sevilla por Sentencia de 21 de Abril de 2006.

Sin embargo, se ha pasado, en los últimos años, de escasamente dos planes subregionales de Ordenación del Territorio aprobados (el de Aglomeración Urbana de Granada y el del Poniente Almeriense), a llevarse a cabo un importante proceso de puesta en marcha acelerada de la planificación de Ordenación del Territorio. El cuadro actual es el siguiente:

\begin{tabular}{|l|c|c|c|c|c|}
\hline \multicolumn{6}{|c|}{ LOS PLANES SUBREGIONALES DE ORDENACIÓN DEL TERRITORIO } \\
\hline A 31 DE JULIO DE 2016 \\
\hline $\begin{array}{c}\text { Ámbitos } \\
2012\end{array}$ & $\begin{array}{c}\text { Núm. } \\
\text { Municipios }\end{array}$ & $\begin{array}{c}\text { Superficie } \\
\left(\mathrm{Km}^{2}\right)\end{array}$ & BOJA & $\begin{array}{c}\text { Estado de } \\
\text { tramitación }\end{array}$ \\
\hline $\begin{array}{l}\text { Aglomeración } \\
\text { urbana de Granada }\end{array}$ & 517.923 & 32 & 859.3 & $28-03-2000$ & Aprobado \\
\hline
\end{tabular}

\footnotetext{
$373 "$.

Véase del autor Urbanismo y Territorio en Andalucía.3 Edición 2012. "Thomson Aranzadi, pág.

4 Véase Urbanismo y Territorio en Andalucía. $3^{\text {a }}$ Edición pág. 374
} 


\begin{tabular}{|c|c|c|c|c|c|}
\hline Poniente de Almería & 248.079 & 9 & 969.7 & 10-10-2002 & Aprobado \\
\hline $\begin{array}{l}\text { Sierra de Segura } \\
\text { (Jaén) }\end{array}$ & 26.649 & 13 & 1.932 .7 & $30-09-2003$ & Aprobado \\
\hline Ámbito de Doñana & 125.401 & 13 & 2.736 .4 & $03-02-2004$ & Aprobado \\
\hline Bahía de Cádiz & 430.276 & 5 & 606.1 & $08-10-2004$ & Aprobado \\
\hline $\begin{array}{l}\text { Costa del Sol } \\
\text { Occidental (Málaga) }\end{array}$ & 379.334 & 9 & 941.5 & 09-10-2006 & $\begin{array}{c}\text { Aprobado/ } \\
\text { Anulado STS } \\
4382 / 2015 \\
\text { de } 22 \text { de Sep- } \\
\text { tiembre }\end{array}$ \\
\hline $\begin{array}{l}\text { Litoral Occidental de } \\
\text { Huelva }\end{array}$ & 105.763 & 7 & 732.1 & 17-07-2006 & Aprobado \\
\hline $\begin{array}{l}\text { Litoral Oriental - } \\
\text { Axarquía (Málaga) }\end{array}$ & 165.224 & 29 & 986.0 & 03-10-2006 & $\begin{array}{c}\text { Aprobado } \\
\text { Decreto } \\
147 / 2006\end{array}$ \\
\hline $\begin{array}{l}\text { Levante de } \\
\text { Almería }\end{array}$ & 90.325 & 11 & 1.198 .8 & $\begin{array}{l}\text { 24-03- } \\
2009\end{array}$ & Aprobado \\
\hline $\begin{array}{l}\text { Aglomeración } \\
\text { Urbana de Sevilla }\end{array}$ & 1.508 .605 & 46 & 4.912 .3 & 09-07-2009 & Aprobado \\
\hline $\begin{array}{l}\text { Aglomeración } \\
\text { Urbana de Málaga }\end{array}$ & 871.491 & 13 & 1.332 .1 & 23-07-2009 & Aprobado \\
\hline $\begin{array}{l}\text { Costa Noroeste de } \\
\text { Cádiz }\end{array}$ & 121.201 & 4 & 360.7 & $19-05-2011$ & Aprobado \\
\hline La Janda & 87.380 & 7 & 1.536 .9 & 21-12-2011 & Aprobado \\
\hline $\begin{array}{l}\text { Aglomeración } \\
\text { Urbana de Almería }\end{array}$ & 251.780 & 9 & 1.158 .9 & 04-01-2012 & Aprobado \\
\hline Campo de Gibraltar & 264.620 & 7 & 1.528 .6 & 19-03-2012 & Aprobado \\
\hline $\begin{array}{l}\text { Costa Tropical de } \\
\text { Granada }\end{array}$ & 127.613 & 17 & 786.7 & 01-02-2012 & Aprobado \\
\hline Sur de Córdoba & 275.443 & 31 & 3.440 .1 & 22-03-2012 & Aprobado \\
\hline $\begin{array}{l}\text { Aglomeración } \\
\text { Urbana de Huelva }\end{array}$ & 239.985 & 8 & 965.8 & & Fase final \\
\hline
\end{tabular}




\begin{tabular}{|l|c|c|c|c|c|}
\hline $\begin{array}{l}\text { Aglomeración } \\
\text { Urbana de Jaén }\end{array}$ & 222.191 & 15 & 1.761 .2 & $3-11-2014$ & $\begin{array}{c}\text { Aprobado } \\
\text { Decreto } \\
142 / 2014 \text { de } 14 \\
\text { de Octubre }\end{array}$ \\
\hline $\begin{array}{l}\text { Aglomeración } \\
\text { Urbana de Córdoba }\end{array}$ & 386.918 & 14 & 2.522 .9 & & En elaboración \\
\hline Almanzora (Almería) & 58.800 & 28 & 1.768 .2 & & En elaboración \\
\hline $\begin{array}{l}\text { Revisión: Bahía de } \\
\text { Cádiz-Jerez (*) }\end{array}$ & 208.896 & 1 & 1.186 .5 & & En elaboración \\
\hline TOTAL POTs $(* *)$ & 6.543 .710 & 315 & 31.650 .8 & & \\
\hline $\begin{array}{l}\text { TOTAL } \\
\text { ANDALUCíA }\end{array}$ & 8.370 .975 & 771 & 87.597 .4 & & \\
\hline ANDALUCíA & 78.2 & 40.86 & 36.1 & & \\
\hline
\end{tabular}

El atraso en la aprobación de los POTS, los escándalos urbanísticos acaecidos en Andalucía y la espiral desarrollista sin fin, marcaron una nueva estrategia de la CA, consistente en la aprobación del POTA por el Decreto 206/2006, de 28 de noviembre, al que se le confirieron determinaciones más propias de los POTS y se procedió incluso a la publicación de algunos Planes de Protección del Medio Físico pretendiendo, 20 años después de su aprobación ${ }^{5}$, subsanar con ello sus irregularidades formales.

Es indudable que el POTA contenía una serie de determinaciones positivas, que hubieran tenido un efecto mucho más beneficioso si se hubieran aprobado 10 años antes. El atraso en su aprobación obligó a introducir determinaciones más rígidas y coyunturales. Como por ejemplo la contenida en la norma 45.4.a), que estableció que no se admitieran los crecimientos que supusieran incrementos de SURBLE superiores al $40 \%$ del Suelo Urbano existente, ni crecimientos que supusieran incremento de población superior al $30 \%$ en 8 años.

En cualquier caso, la entrada en vigor de la LS07, el 1 de julio de 2.007, puso fin a la liberalización indiscriminada del suelo, otorgándole a todo el suelo rural un valor digno de ser protegido. Si a esta nueva legislación básica estatal en la que se

\footnotetext{
Por resolución de la Dirección General de Urbanismo de 14 de febrero de 2007 (BOJA 9-42007), se dispuso la publicación del Plan Especial de Protección del Medio Físico y Catálogo de Espacios y Bienes Protegidos de la Provincia de Málaga. Este Plan fue aprobado por resolución de 6 de Marzo de 1987 del COPT.
} 
incardina el POTA, le sumamos las interpretaciones restrictivas para coordinar el desarrollo urbanístico con el modelo territorial incorporado en el POTA, junto a la crisis inmobiliaria, la consecuencia fue un frenazo casi total a los nuevos crecimientos urbanísticos en la CAA. Por ello, ante el riesgo de una paralización total en el desarrollo urbanístico, se dictaron dos normas reglamentarias que marcaban un camino más flexible para el desarrollo urbanístico, eso si, dependiendo en gran medida de la discrecionalidad autonómica.

En primer lugar, se aprobó el Decreto 11/2008 por el que se desarrollaban procedimientos dirigidos a poner suelo urbanizado en el mercado con destino preferente a la construcción de viviendas públicas y se contemplaba un procedimiento de adaptación del planeamiento vigente anterior a la aprobación de la LOUA, que permitiría, una vez aprobada que se pudieran producir reclasificaciones puntuales.

Y en segundo lugar, el Decreto 43/2008 de 12 de febrero de 2.008 de Campos de Golf. Esta norma ha establecido dos tipos de campos de golf. Los incluidos en el PGOU, de competencia municipal, sin perjuicio de la intervención autonómica en su autorización, que no pueden tener uso residencial y comercial como uso complementario. Y los considerados de interés turístico, que están en el ámbito competencial autonómico, debiendo figurar en los POTS y que tienen la posibilidad de incluir uso residencial y comercial entre otros. Pero la realidad ha sido que estas dos normas han tenido poca incidencia en la gestión urbanística de Andalucía.

A finales del 2012 se aprobó el Decreto Ley 5/2012, de 27 de noviembre, de medidas urgentes en materia urbanística y para la protección del litoral de Andalucía. Mediante este Decreto-Ley se crea la figura del Plan de Protección del Corredor Litoral de Andalucía que se incorpora a la planificación territorial mediante la modificación de la LOTA, situándose jerárquicamente por debajo del POTA y por encima de los POTS. En su artículo 3 estableció medidas urgentes de adecuación del planeamiento urbanístico al Plan de Ordenación del Territorio de Andalucía. Además se subsanan los problemas formales que habíamos apuntado, modificando el art. 22.1 de la LOTA, estableciendo que el POTA será vinculante para el resto de los instrumentos de planificación territorial, incluyendo los planes urbanísticos generales.

Por Decreto 141/2015, de 26 mayo, se ha aprobado el Plan de Protección del Corredor Litoral de Andalucía que será vinculante para todos los planes territoriales y urbanísticos, excepto para el POTA. Tampoco prevalecerá sobre las determinaciones de los planes de Ordenación de Recursos Naturales, cuyo ámbito de aplicación coincida sobre el Plan de Protección del Corredor Litoral. 


\subsection{Las modificaciones de la LOUA para su adaptación al TRLS08}

Al contrario que otras Comunidades Autónomas, en Andalucía no se había producido hasta el año 2012, modificación alguna de la LOUA para adaptarse al Texto Refundido Ley de Suelo, aprobado por RDL 2/2008 de 20 de junio (TRLS08), salvo la modificación de su art. 75.2.d) por la Ley 11/2010, de 3 de diciembre de medidas fiscales para la reducción del déficit público y para la sostenibilidad, que modificó el régimen de los ingresos del PMS, unificándolo con el de los bienes. Las modificaciones más destacadas, introducidas en la LOUA por la Ley 2/2012, en materia de suelo, Ordenación, Patrimonio Municipal de Suelo, Ejecución del Planeamiento y Disciplina fueron las siguientes:

a) Régimen del Suelo.- En relación al suelo urbano, se modifica el art. 45.2.B) a fin de precisar el concepto de suelo urbano no consolidado. Se incluye un apartado a) que considera SUNC a los terrenos que constituyan vacíos relevantes que permitan la delimitación de sectores de suelo que carezcan de los servicios, infraestructuras y dotaciones públicas precisas y requieran de una actuación de renovación urbana que comporte una nueva urbanización concertada funcionalmente a la red de los servicios e infraestructuras existentes. El apartado b) se refiere a los SUNC sometidos a reforma interior sin que se introduzcan cambios de interés y en el apartado c) se incluye propiamente el tipo de SUNG sujeto a una actuación de dotación, por precisar un incremento o mejora de los servicios públicos y de la urbanización existente o de dotaciones como consecuencia de un aprovechamiento objetivo derivado de un aumento de edificabilidad, densidad o de cambio de uso, con respecto al aprovechamiento existente que el instrumento de planeamiento atribuya en parcelas integradas en áreas homogéneas. Dentro de este apartado se ha regulado este aprovechamiento objetivo, presumiéndose que este incremento requiere el aumento o mejora de las dotaciones y en su caso de los servicios públicos y de urbanización, cuando comporte un aumento del aprovechamiento objetivo superior al diez por ciento del preexistente.

En cuanto al SNU, se modifica el apartado 1.g) del art. 46 para cambiar la definición de Hábitat Rural Diseminado, suprimiéndose la vinculación a la actividad agropecuaria, que solo se contempla en origen.

En lo referente a las actuaciones de transformación urbanística, a través de actuaciones de dotación, se ha establecido su régimen jurídico a través del nuevo apartado 3 del art. 55 que posibilita la ubicación de las dotaciones en un entorno próximo, cuando el grado de ocupación por la edificación del área haga inviable su ubicación total o parcial. Por otra parte se establece que para mantener la proporcionalidad y la calidad de los suelos dotacionales, se calcularán conforme a la media dotacional resultante de la zona de suelo urbano en que estén incluidos y la proporcionalidad y suficiencia de los sistemas generales alcanzada en el municipio. Esta cesión sólo 
puede ser sustituida, de manera motivada por su equivalente en dinero, cuando, en el ámbito de una modificación de planeamiento, los terrenos no tengan la suficiente calidad y entidad para quedar integrados en la red de dotaciones públicas.

b) Ordenación Urbanística.- Se amplían los fines específicos de la actividad urbanística. Al efecto, el art. 3 añade dos apartados, el i) que recoge la promoción de la igualdad de género y el j) que establece como objetivo el establecimiento de medidas para evitar la presencia en el territorio de edificaciones y asentamientos ejecutados al margen de la legalidad urbanística.

Se permite, al igual que en otras Comunidades Autónomas, que se pueda destinar suelo de equipamiento público a alojamientos transitorios de promoción pública, pero la edificabilidad que se les atribuya, no computara a efectos del porcentaje de reserva de protección oficial.

Se prevé que los PGOU establezcan como determinación estructural una horquilla de densidad en varios tramos, y formará parte de la ordenación pormenorizada, que es de competencia municipal, su determinación dentro de esta horquilla.

En lo referente a los Planes Parciales, se establece que puedan efectuarse alteraciones en el plan de etapas mediante el procedimiento de delimitación de unidades de ejecución, sin necesidad de la modificación del Plan Parcial.

En los Sectores de suelo urbano no consolidado y suelo urbanizable se autoriza el aumento de la densidad de 75 a 90 viviendas por hectáreas pero permanece igual la edificabilidad, (un metro cuadrado de techo por metro cuadrado de suelo). Igual ocurre en las áreas de reforma interior, la densidad aumenta hasta el máximo de 120 por hectáreas, pero la edificabilidad permanece en un máximo de 1,3 metros cuadrados por metro cuadrado de suelo.

Se obliga a incorporar dentro del estudio económico-financiero del planeamiento, un informe de sostenibilidad económica, que debe contener la justificación de la existencia de suelo suficiente para usos productivos y su acomodación al desarrollo urbano previsto en el planeamiento. Debe incluirse igualmente un análisis de las actuaciones previstas en las Haciendas de las Administraciones Públicas que sean responsables de la implantación y el mantenimiento de las infraestructuras y servicios necesarios.

Se introducen modificaciones tendentes a simplificar el procedimiento de aprobación del Planeamiento y a procurar una mayor garantía de los propietarios.

c) Incidencia en el PMS.- La Ley 11/2010, de 3 de diciembre modificó la LOUA, adaptándola al TRLS08, introduciendo la unificación del destino de bienes e ingresos. Previamente la Ley 13/2005, de 11 de noviembre, había modificado la LOUA, 
preceptuando que cuantas aportaciones económicas, obtenidas en virtud del convenio, independientemente del concepto al que obedecieran, deberían integrarse en el patrimonio público del suelo.

A su vez la modificación introducida por la Ley 2/2012 zanjó la cuestión, en lo referente a los gastos de urbanización, provenientes de los convenios, al excluirlos de la obligación de incorporación al PMS. No ha extendido, en cambio, esta excepción a los ingresos provenientes de los convenios y destinados a la adquisición de dotaciones obligatorias recogidas en el art. 51.1 c) d) de la LOUA, pero igualmente, habrá que seguir interpretando, que el destino específico de estos ingresos, es a la adquisición de dichas dotaciones y no a los fines generales del PMS. ${ }^{6}$

d) Ejecución Ordenación Territorial y Urbanística.- Se modifica el art. 96, adicionando como exigencia para efectuar los actos jurídicos de ejecución necesarios, además de la delimitación de la unidad de ejecución y la elección del sistema de actuación, la inclusión de unas bases orientativas para su ejecución relativas, al menos, a calidades, plazos y diseño urbano, con el grado de determinación suficiente para calcular los gastos de urbanización imputables a la actuación. Además se establece un plazo de prioridad para los propietarios, en el sistema de compensación, de nueve meses, a partir que se den los requisitos del art. 96, que hemos señalado y un derecho de consulta a la Administración competente, que deberá ser evacuado en dos meses, sobre los criterios y previsiones de la ordenación urbanística, vigente y en tramitación, y las obras a realizar para conectar la urbanización con las redes generales de servicio y en su caso mejora de las existentes.

Por otra parte, se mejora la regulación del agente urbanizador. Así se incorpora un art. 97 bis, que dice que éste obtiene la legitimación para intervenir en la ejecución urbanística, tras su elección en pública concurrencia por la Administración actuante y la suscripción del convenio urbanístico regulador de la actuación urbanizadora conforme a lo dispuesto en la LOUA y supletoriamente en la legislación de contratación del sector público para el contrato de gestión de servicio público.

e) Disciplina urbanística.- Las licencias urbanísticas no se adaptaron a la Directiva de Servicios, ni a la legislación estatal, no estableciendo los supuestos en los que procedería la comunicación previa o declaración responsable y en los que el silencio sería positivo. Si se estableció, el carácter real de las medidas de protección de la legalidad urbanística y restablecimiento del orden jurídico perturbado, lo que

6 GUTIÉRREZ COLOMINA, Venancio. Manual Práctico de Derecho Urbanístico de Andalucía. Pág. 730. CEMCI. Granada 2009. 
comporta que puedan exigirse frente a cualquiera que resulte ser el actual propietario de la edificación o finca controvertida.

Se da cobertura legal a la situación de asimilación a la situación de fuera ordenación contemplada en el RDUA. Se modificó el plazo para la caducidad de las medidas de protección de la legalidad, que aumenta de 4 a 6 años. Por último se regula la recuperación de dotaciones y aprovechamiento urbanístico en actuaciones irregulares en suelo urbano, comportando, entre otras cosas, que la resolución administrativa firme que acuerde la reposición de la realidad física alterada, solo se entenderá ejecutada por equivalencia, cuando haya sido íntegramente satisfecha la indemnización prevista en la resolución. (nueva Disposición Adicional novena de la LOUA).

1.4.- Regulación de edificaciones ilegales en el SNU.- Los pequeños municipios de Andalucía, carecen en muchos casos de planificación urbanística y de una estructura técnico jurídica adecuada para la gestión y el control urbanístico, estando los gobiernos municipales sometido por ello a una gran incertidumbre para mantener el orden urbanístico, lo que sitúa a éstos en muchas ocasiones, en riesgo involuntario de cometer infracciones urbanísticas e incluso en la posibilidad de incurrir en actos punitivos en vía penal (prevaricación o delitos contra la ordenación del territorio). Hay que partir como idea clave que un desarrollo sostenible y ordenado, que comprenda funciones productivas así como incluso una cierta función residencial no es rechazable y puede mejorar la situación económica de estos municipios. Para ello sería imprescindible regular con claridad la función residencial en el SNU.

En Andalucía se ha producido una confusión conceptual entre la vivienda familiar aislada y la agrícola, dando como resultado una gran incertidumbre jurídica en el régimen de la primera. Esta confusa regulación ha dado paso en Andalucía a una gran cantidad de viviendas ilegales en el Suelo No Urbanizable, habiéndose dictado para resolver este tema, de manera específica, el Decreto 2/2012, de 10 de enero por el que se regula el régimen de las edificaciones y asentamientos existentes en suelo no urbanizable en la Comunidad Autónoma de Andalucía

Pero ¿La solución para la regularización de las edificaciones actualmente existentes en el SNU, por el Decreto 2/2012, ha ido más allá de lo regulado en la LOUA? ¿ha producido una amnistía encubierta?. Puede contestarse que no ha supuesto una amnistía para las edificaciones ilegales, puesto que no ha alterado los plazos para ejercer la acción de restauración del orden urbanístico infringido, que incluso, se han ampliado ahora a 6 años por la ley 2/2012. Y además el Decreto 2/2012 no ha producido una solución global de los problemas que origina la actividad residencial en el SNU, aunque si ha ofrecido una solución parcial para las edificaciones existentes, contra las que no cabe el ejercicio de las medidas de protección de la legalidad. Son 
edificaciones que permanecen en una especie de limbo jurídico porque son inatacables jurídicamente, pero no están incorporadas plenamente a la legalidad y tienen problemas de dotación de infraestructuras, de servicios y registrales. Esta regularización se extiende igualmente a las edificaciones ilegales con imposibilidad legal o material de ejecutar la resolución de reposición de la realidad física.

Intentando solucionar estas cuestiones, el Reglamento de Disciplina Urbanística de Andalucía, (RDUA) aprobado en 2010, ya incluyó algunas novedades para hacer frente a esta situación. No obstante, la rígida regulación que hizo de la situación de fuera de ordenación, y de asimilado a dicha situación, impidió que tuviera algún efecto positivo. El Decreto 2/2012, ha abordado la solución del problema de las edificaciones existentes en el SNU, a través del establecimiento de distintos tipos de vivienda y de su grado de adecuación al ordenamiento jurídico, utilizando el PGOU como instrumento clave para conseguir la regularización. Diferencia básicamente las edificaciones, según que su forma de implantación sea de Edificación aislada, Asentamiento Urbanístico y Hábitat Rural Diseminado. Y dentro de las edificaciones aisladas distingue tres regímenes jurídicos: Edificaciones legalizadas o legalizables, en situación legal de fuera de ordenación y de asimilación a la fuera de Ordenación. Por otra parte estarían las edificaciones existentes, pendientes de adopción de medidas de protección de la legalidad.

Como consecuencia del carácter residual de las edificaciones aisladas, es necesario la previa delimitación de los asentamientos urbanísticos existentes por el PGOU o por el Avance de Planeamiento con naturaleza jurídica de Ordenanza Urbanística. Por otra parte, los Ayuntamientos, mediante la revisión total o parcial del PGOU, incorporaran a la ordenación urbanística los terrenos de los asentamientos urbanísticos existentes en el suelo no urbanizable de su término municipal, que por el grado de consolidación de las edificaciones o por su integración con los núcleos urbanos existentes, resulten compatibles con el modelo urbanístico y territorial del municipio.

En todo caso, conviene resaltar que no procederá la incorporación, entre otros al planeamiento urbanístico de los asentamientos que se encuentren ubicados en suelo no urbanizable de especial protección por legislación especifica que sean incompatibles con el régimen de protección,en suelo no urbanizable de especial protección por la planificación territorial, salvo que resulten compatibles con el régimen establecido por estos planes, en suelo no urbanizable protegido por el planeamiento urbanístico en vigor salvo que se acredite la inexistencia de los valores que determinaron la protección de dichos terrenos y siempre que la desaparición de esos valores no haya sido provocado por el propio asentamiento.

El Decreto 2/2012 parece considerar que los asentamientos que no deban ser incorporados a la ordenación establecida por el Plan General de Ordenación Ur- 
banística, constituyen, de hecho, una parcelación ilegal. Y por ello establece que se adoptarán las medidas que procedan para el restablecimiento de la legalidad urbanística y del orden jurídico infringido sobre éstos. Aunque debe tenerse en cuenta que la no caducidad de la acción para restaurar el orden urbanístico en una parcelación ilegal en SNU, fue incorporada por la LOUA y por tanto, como es obvio, pueden existir estos asentamientos con anterioridad a la vigencia de ésta y puede por ello haber caducado, en ese caso, la acción de protección de la legalidad. Como decíamos en la $2^{a}$ edición de Comentarios a la Ley de Ordenación Urbanística de Andalucía, conviene destacar "que no rige la limitación temporal de los cuatro años(actual de seis años) desde la terminación de la parcelación ilegal en el SNU para la reposición de la realidad física alterada". Pero si conviene destacar que, en el caso, de edificaciones ilegales en el SNU que no sean de especial protección, si rige el plazo de seis años (art. 185.4 LOUA), para restaurar la legalidad.

Por ello se puede producir un grave problema de legalización de la actuación, en el caso, que hayan transcurrido los seis años y exista una edificación ilegal junto con una parcelación ilegal en un SNU que no sea de especial protección”. Porque en nuestra opinión habría caducado la acción para restaurar el orden urbanístico en el caso de las edificaciones, si el SNU no era protegido, pero no había caducado la acción para poner fin a la parcelación ilegal, por lo que la fórmula que proponíamos era la reagrupación en una parcela indivisible de todas las parcelaciones existentes y de las edificaciones existentes bajo el régimen del mantenimiento de propiedad horizontal o conjunto inmobiliario de acuerdo con el art. 82 del RD 1093/1997.

Sin embargo, el desarrollo reglamentario no siguió el camino que habíamos indicado, sino que el articulo 49.2 RDUA estableció, refiriéndose a la resolución que ponga fin al procedimiento de reposición de la realidad física alterada en el caso de parcelaciones ilegales en el SNU que dicha resolución podrá adoptar las siguientes medidas que no tienen carácter excluyente:

“j) En el caso de parcelaciones urbanisticas en terrenos que tengan el régimen del suelo no urbanizable, el restablecimiento del orden jurídico perturbado se llevará a cabo mediante la demolición de las edificaciones que la integren y reagrupación de las parcelas, a través de una reparcelación forzosa de las que han sido objeto de dichos actos de previa parcelación”...

Con el objetivo abordar de manera diferente al RDU, la solución del problema planteado, se ha aprobado en el Parlamento de Andalucía la Ley 6/2016, de 1 de agosto, por la que se modifica la Ley 7/2002, de 17 de diciembre, de Ordenación Urbanística de Andalucía para incorporar medidas urgentes en relación con las edificaciones construidas sobre parcelaciones urbanísticas en suelo no urbanizable. En su artículo único modifica los arts. 68.2, 183.3 y 185.2 de la LOUA. 
Esta Ley de modificación de la LOUA, sí que es realmente una amnistía encubierta para unas determinadas edificaciones ilegales. En efecto, ello es así, porque sólo viene a resolver el problema de las edificaciones ilegales existentes dentro de una parcelación ilegal, para las que haya pasado el plazo de 6 años siguientes a su completa terminación, pero no resuelve el problema de las edificaciones ilegales en los Suelos No Urbanizables de Protección Territorial, que como hemos dicho, no tienen unos valores que conlleven una específica protección pero que como se le da el carácter de especial protección la acción para demoler no caduca nunca, por lo que salvo que se flexibilice en los Planes de Ordenación Territorial ${ }^{7}$ esta especial protección, la modificación de la LOUA por la Ley 6/2016, no servirá para mucho. En efecto, según el apartado tres de su artículo único esta excepción de limitación temporal de la caducidad de la protección de la legalidad, únicamente será de aplicación a la parcela concreta sobre la que se encuentre la edificación en la que concurran los citados requisitos, no comprendiendo al resto de parcela o parcelas objeto de la parcelación. No se resuelve el problema de la reposición física de las parcelaciones ilegales que se produzcan en el futuro, puesto que es indudable que se van a seguir produciendo, y la subsistencia de la regulación del art.49.2 j que comporta la restauración del orden urbanístico, a través de la demolición y la reagrupación de parcelas, no va a ser fácil de llevar a cabo en la práctica, y va a producirse un agravio comparativo con las "amnistiadas" por la Ley 6/2016.

\section{LA DOGTRINA JURISPRUDENGIAL RELEVANTE AGERGA DE LA NULIDAD DE LOS PLANES GENERALES POR APLICA- CIÓN DEL DERECHO URBANISTICO DE ANDALUCIA}

\section{Ideas generales}

En relación con esta cuestión conviene poner de relieve en primer lugar, que es indudable que el desarrollo invertido y poco sistemático del proceso legislativo que hemos analizado anteriormente y la gran cantidad de conceptos jurídicos indeterminados incorporados a la legislación urbanística de Andalucía, a que hemos hecho referencia, ha tenido una clara influencia en una serie de Sentencias que han provocado la nulidad del planeamiento urbanístico, en unos casos y en otros la nulidad parcial o total de algunos instrumentos de la planificación del territorio de Andalucía. Entre estas Sentencias, estarían las Sentencias recaidas sobre el Plan General

Véase arts 70 y 71 de las Normas Urbanísticas del Plan de Ordenación Territorial de la Aglomeración Urbana de Málaga que regula la zona de protección territorial. 
de Ordenación Urbanística de Marbella, destacando dentro de estas las SsTS 27X-2015 rec. 313/2014, 27-x-2015 .rec. 2180/2014 y 28-X-2015 .rec. 1346/2014 y por otra parte estarían las siguientes: STS 272/2016 de 10 de febrero Jur/2016/36531 sobre el Algarrobico, y STS 404/2016 de 16 de febrero de 2016, sobre nulidad parcial del Plan de Ordenación Territorial de la Aglomeración Urbana de Málaga (POTAUM). Y las del Tribunal Superior de Justicia de Andalucía de 9 de febrero 2015 sobre nulidad parcial del Plan de Ordenación Territorial de la Aglomeración Urbana de Málaga por prevalencia de la Ley de Costa y la STS 4382/2015 que anula el Plan de Ordenación del Territorio de la Costa del Sol Occidental de la provincia de Málaga por no dar respuesta a las alegaciones formuladas.

Y en segundo lugar, hay que destacar los efectos tan negativos que estas Sentencias han producido en la actividad socioeconómico de Andalucía, puesto que como consecuencia del carácter y naturaleza jurídica de la Planificación urbanística y territorial, los efectos jurídicos que se producen por su ilegalidad, sea la causa que sea, es el de la nulidad de pleno derecho, de acuerdo con lo que dispone el art. 62.2 de la ley de régimen jurídico y procedimiento administrativo común (La LPAC en vigor a partir del 2 de Octubre del año 2016 mantiene la misma regulación en su art.47.2).

En las páginas que siguen vamos a hacer un estudio de las principales causas que han provocado la nulidad de los planes urbanísticos y de los de ordenación territorial, así como las traumáticas consecuencias que se originan, sobre todo en orden a la demolición de las viviendas irregulares, realizando una reflexión final sobre las propuestas y soluciones para mitigar los efectos que se producen como consecuencia de las Sentencias que conllevan la nulidad de los planes generales de ordenación Urbanística.

\section{Motivos nulidad}

2.1- Limitación del PGOU y de la Planificación de Ordenación del Territorio por el Régimen del Suelo.- No está en manos del planificador alterar o desfigurar el concepto de SUG ni el de SNUEP.- Una de las limitaciones más importantes que tiene la discrecionalidad administrativa a la hora de aprobar los Planes urbanísticos es el respeto al régimen del Suelo, y dentro de ello, está el respeto al carácter reglado del suelo urbano (SU) y del Suelo No Urbanizable de especial protección. (SNUEP).

A) Carácter reglado del Suelo Urbano.- Como señalaba GONZÁLEZ PÉREZ ${ }^{8}$ el planificador no era libre para clasificar el suelo urbano sino que solo se podían clasificar unos terrenos como urbano cuando se daban las circunstancias del apartado a)

\footnotetext{
GONZÁLEZ PÉREZ, Jesús. «Comentarios a la Ley del Suelo». I. Cívitas 1993. Pág. 193.
} 
del art. 10 del TR/1992, es decir, «Los terrenos a que el planeamiento general incluya en esa clase por contar con acceso rodado, abastecimiento de agua, evacuación de aguas y suministro de energía eléctrica, debiendo tener estos servicios características adecuadas para servir a la edificación que sobre ellos exista o se haya de construir». También se considerarán urbanos «los terrenos que tengan su ordenación consolidada por ocupar la edificación al menos dos terceras partes de los espacios aptos para la misma según la ordenación que el planeamiento general establezca»; o los del apartado b), «Los que en ejecución del planeamiento lleguen a disponer efectivamente de los mismos elementos de urbanización a que se refiere el párrafo anterior».

La jurisprudencia así lo había establecido al señalar que: «La inclusión o no por el Plan de unos terrenos como suelo urbano queda fuera de la esfera voluntarista de la Administración, es decir, que ésta se ha de limitar en este punto a contrastar la realidad física para declarar como suelo urbano el que según la Ley reúne los caracteres necesarios para ello» (STS de 30 de enero de 1991).

La STS de 21 enero 1992 señalaba que la clasificación de unos terrenos como suelo urbano exige no simplemente que los terrenos estén dotados de acceso rodado, abastecimiento de aguas, evacuación de agua residuales y suministro de energía eléctrica, con las características adecuadas para servir a la edificación que sobre ellos exista o se haya de construir, sino también que tales dotaciones procedan precisamente de los servicios y que el suelo esté inserto en la malla urbana, de modo que exista una urbanización básica constituida por unas vías perimetrales y unas redes de suministro de agua y de energía eléctrica y de saneamiento de que puedan servirse los terrenos y estos, por su situación, no estén desligados completamente del entramado urbanístico ya existente.

Este criterio fáctico del suelo urbano, recogido jurisprudencialmente, también ha sido recogido normativamente, como es el caso de la legislación de Costas. Así, en la disposición transitoria tercera.3 de la Ley 22/1998, de 28 de julio, de Costas se estableció que "los terrenos clasificados como suelo urbano a la entrada en vigor de la presente ley estarán sujetos a las servidumbres establecidas en ella, con la salvedad de que la anchura de la servidumbre de protección será de 20 metros". (Esto ha sido recogido de la misma manera en la Disposición transitoria décima del Reglamento General de Costas RD 876/2014). En el desarrollo de esta disposición, el Reglamento de Costas, aprobado por el Real Decreto 147/1989, de 1 de diciembre, (actualmente derogado por RD 876/2014 de 10 de Octubre por el que se aprueba el Reglamento General de Costas) acudió a criterios fácticos. Así la disposición transitoria séptima.3 estableció que en "los municipios que carezcan de instrumentos de ordenación se aplicarán íntegramente las disposiciones sobre las zonas de servidumbre de protección e influencia, salvo que se acredite que en la fecha de entrada en vigor de la citada ley 
los terrenos reunían los requisitos exigidos por la legislación urbanística para su clasificación como urbano". Y en la disposición transitoria novena.3 señalaba que a los efectos de la aplicación de la servidumbre de protección "se considera suelo urbano no solo el que tenga esta clasificación establecida por los instrumentos de ordenación vigentes en la fecha de entrada en vigor de la ley de Costas sino también cuando se trate de áreas urbanas en las que la edificación estuviera consolidada o los terrenos dispusieran de los servicios exigidos en la legislación urbanística en la citada fecha y la Administración urbanística competente les hubiera reconocido expresamente ese carácter". (Esto se recoge igualmente por la Disposición transitoria décima apartado 3 del Reglamento 876/2014 de 10 de Octubre). Además la Disposición transitoria vigésimo segunda del Reglamento 876/2014 ha ampliado los supuestos fácticos para la consideración de suelo urbano en desarrollo de la DT primera de la ley 2/2013, de 29 de mayo, de protección y uso sostenible del litoral y de modificación de la ley 22/1988, de 28 de julio, de Costas.

Existen sentencias específicas que recogen el carácter reglado del SU y que se refieren concretamente a la Ley de Costas, así la STS de 17 de noviembre de 2003, señala en su FD Primero que "No es acertado el razonamiento jurídico de la Sala de instancia y debemos por tanto, estimar el motivo de casación en que se sustenta este recurso, en el que se denuncia la infracción de la Disposición Transitoria Tercera de la Ley de Costas y la jurisprudencia que ha consagrado el criterio de la fuerza normativa de lo fáctico para imponer la obligada consideración de un suelo como urbano". En el FJ cuarto señala que es también demostrativo de que "el citado Reglamento no introduce la exigencia de una previa clasificación en tal sentido como necesaria para considerar un suelo como urbano, el tenor del número 3 de su Disposición Transitoria Séptima, en el que se prescribe: "3. En los municipios que carezcan de instrumentos de ordenación se aplicarán íntegramente las disposiciones de la Ley de Costas y de este Reglamento sobre las zonas de servidumbre de protección y de influencia, salvo que se acredite que en la fecha de entrada en vigor de la citada Ley los terrenos reunían los requisitos exigidos por la legislación urbanística para su clasificación como suelo Urbano".

La Sentencia de 11 de Septiembre, de 2008 ha distinguido entre los dos caminos por los que se llega a adquirir el carácter urbano: la clasificación o la fuerza de lo fáctico.

A efectos de la norma debe considerarse reconocimiento expreso, tanto la resolución expresa de la Administración urbanística reconociendo la existencia del área urbana, como la resolución judicial reconociendo dicho carácter pese al criterio contrario de la Administración. Reconocimiento que por lo demás será declarativo, no 
constitutivo, es decir, que la Administración deberá limitarse a declarar, en su caso, lo que "ex lege", ya es suelo urbano.

B) La naturaleza reglada del SNU de especial protección.-Igualmente cabe afirmar que la calificación de un suelo como de especial protección escapa de la esfera voluntarista de la Admón. Como hemos señalado en otro lugar. ${ }^{9}$ La Jurisprudencia ha ido limitando la discrecionalidad de la Admón. para calificar un SNU como de especial protección. Así el TS en S de 8 de octubre de 1990 dice que «la realidad de los hechos, por un lado, y la coherencia necesaria en el desarrollo de los criterios de planificación, por otro, determinan la conclusión de que la calificación litigiosa no se ajusta a las exigencias de racionalidad en la actuación administrativa». El TSJ de Andalucía, en S de 14 de noviembre de 1994 señaló que la ausencia de cultivos en la franja donde se pretende construir, constatada mediante datos objetivos, no lesiona «ninguno de los valores especificos que se pretenden proteger». La STS de 15 de noviembre de 1995 ha señalado, por su parte, que la calificación del SNU de especial protección ecológica no está dentro del libre arbitrio del planificador, sino que ha de respetar el criterio real en su delimitación. Afirma, por tanto, que constituye «uno de los supuestos, junto con la calificación de suelo urbano, en el que priva el criterio real en la delimitación». En este sentido la STSJ de Cantabria de 18 de enero de 2000 considera incongruente una calificación de SNU de especial protección «que resultaba absolutamente contradictoria con la realidad natural de los terrenos». La sentencia $\mathrm{n}^{\circ}$ 484/2001, de 21 de abril, del Tribunal Superior de Justicia de la Comunidad Valenciana, establece la obligación de clasificar como suelo no urbanizable especialmente protegido de la zona Húmeda la Marjal, en el Municipio de Masamagrell. La STS de 14 de febrero de 2007, reitera la STS de 15 de noviembre de 1995, excluyendo la libertad del planificador para incluir o excluir de la categoría de especial protección la Montaña del Puig.

2.2. Análisis de la jurisprudencia que ha originado la nulidad del planeamiento territorial y urbanístico por incidir en el carácter reglado del Suelo Urbano y del SNUEP

A) PGOU de Marbella.- En relación con este tema, si analizamos alguna de estas cuestiones en las Sentencias del Tribunal Supremo, que han provocado la nulidad del PGOU de Marbella, podemos señalar que en ellas se establece en primer lugar que de acuerdo con esta consideración del carácter reglado del Suelo urbano, era improcedente considerar determinados terrenos como suelo urbano no consolidado por tratarse en realidad de Suelo Urbano consolidado.

La doctrina del Tribunal Supremo ha venido señalando que la diferenciación entre las dos categorías de suelo urbano consolidado y no consolidado estaba prevista

$9 \quad$ Urbanismo y Territorio en Andalucía. $3^{\text {a }}$ Edición. Pág. 498. 
en la legislación estatal, en concreto en el art. 14 de la Ley 6/1998, de 13 de abril sobre el Régimen del Suelo y Valoraciones (LRSV). En el apartado 1 del anterior artículo se dispensa de los deberes de equidistribución a los propietarios del suelo urbano consolidado. Está constitucionalmente validado por la STC 164/2001 ,la distinción establecida por la ley estatal ( la LRSV, actualmente derogada)al señalar: "la exclusión de toda cesión obligatoria de aprovechamiento urbanístico en SUC no admite modalización alguna de origen autonómico".

Según STS de 27 de Octubre de 2015, recurso 313/2014, si, se establece esta diferenciación en la legislación autonómica, debe ser interpretado en compatibilidad con la legislación estatal, pero la interpretación del art.45.2.b.a)1) de la LOUA tendría que hacerse con arreglo al art. 9 del TRLS08 y no con arreglo al art. 14.1 que estaba derogado cuando se aprobó el PGOU de Marbella, aunque según el TG esta delimitación entre una y otra categoría de suelo urbano y el correspondiente régimen de deberes habrá de ejercerse "en los límites de la realidad". Por ello el TS, a partir de la doctrina contenida en la STS de 23 de Septiembre de 2008, reiterada posteriormente en distintas Sentencias, mantiene que no resulta admisible que unos terrenos que indubitadamente cuentan no solo con los servicios exigibles para su consideración como suelo urbano, sino también con los de pavimentación de calzada, encitado de aceras y alumbrado público, y que están plenamente consolidados por la edificación pierdan la consideración de suelo urbano consolidado, pasando a tener la de suelo urbano no consolidado, por la sola circunstancia que el nuevo planeamiento contemple para ellos una determinada transformación urbanística."

Por ello, señala el TS, que conforme a lo expuesto, no resulta jurídicamente aceptable, constituyendo una técnica que debe censurarse, el generalizado recurso a la categoría del SUNC, como fórmula empleada de manera indiscriminada y como modo de tratar de solventar todas las patologías en que se haya podido incurrir con anterioridad a la Revisión de un PGOU. Y por ello, como señala la STS de 2 de octubre de 2013 (RC 3970/2010 (La Ley 152745/2013) "Quizá resulte aconsejable también que, aun en el caso de existencia de los servicios urbanísticos que denotan la pertenencia al urbano, cuando éstos proceden de ejecuciones irregulares, esto es, al margen del planeamiento, no se impone su clasificación como urbanos, ya que se llegaría al resultado, jurídicamente inadmisible, de que las ilegalidades urbanísticos se impondrían por la fuerza de los hechos".

Aunque no puede de dejar de considerarse que estas Sentencias del Tribunal Supremo no han tenido en cuenta que el art.12 TRLS08 exigía, para el suelo urbanizado que debía contar con las dotaciones y servicios requeridos por legislación autonómica y que se establecían en el propio TRLS08 deberes para transformación urbanística según art. 14.1.a)(reforma o renovación suelo urbanizado). Y que además, 
en la actualidad el art.17.2 del vigente Texto Refundido de la Ley del Suelo y Rehabilitación Urbana, aprobado por Real Decreto Legislativo 7/2015, de 30 Octubre, (TRLSRU) impone el régimen de equidistribución en actuaciones sobre el medio urbano. Y que también olvida que la doctrina del Tribunal Constitucional sobre el régimen de los deberes que han de llevarse a cabo "en los límites de la realidad sin admitir modalización autonómica alguna, contenida en la STC 164/2001, se ha vuelto a interpretar por el propio TG en su Sentencia 94/2014, de 12 de Junio de 2014, distinguiendo entre un suelo urbano no consolidado "el integrado por los suelos que, aun formando parte de la ciudad - consolidados por la edificación que carecen de una urbanización completa, es decir no cuentan con todos los servicios, urbanos. Son los denominados suelos urbanos no consolidados de primera urbanización, bolsa de suelo dentro de la ciudad ya formada, más o menos, edificados pero apenas urbanizados o no urbanizados por completo". Y por otra parte, entre otro suelo que forma parte del suelo urbano, sin que la legislación estatal precise, si se trata de suelo urbano consolidado o no, por lo que puede ser cualquiera de los dos y que se definen como aquellos que "a pesar de contar con todos los servicios del suelo urbano, requieren de una operación de reforma o renovación interior. Son suelos urbanos consolidados por la urbanización para los que por diferentes causas (obsolescencias de los servicios, degradación del barrio, modificación del uso característico o eliminación de polígonos industriales en el centro de la ciudad, etc), el planeamiento impone su reurbanización integral." Y su inclusión como suelo urbano consolidado o no depende de la legislación autonómica. Por lo que está claro para la doctrina constitucional actual, que el suelo destinado a las operaciones de regeneración, rehabilitación y renovación urbana, si permite modalización autonómica, aunque tenga las características de suelo urbano consolidado, pero sería mediante su transformación por la legislación autonómica en suelo urbano no consolidado.

B) Mantenimiento del carácter reglado en servidumbre de protección de la Zona Marítimo Terrestre.- El Suelo urbano mantiene el carácter reglado en la servidumbre de protección de la zona marítima terrestre. El plan de Ordenación Territorio de la Aglomeración Urbana de Málaga, aprobado por Decreto 308/2009 (POTAUM) remitía en su art.55 a la regulación de la utilización del DPMT a la Ley de Costas. En el art. 69.1.d) del POTAUM se recoge la ZMT dentro de la zona de protección ambiental y se dispone en su art. 69.2 que estos suelos tendrán en el PGOU la clasificación de SNU de especial protección. La Dirección General de Urbanismo estableció la clasificación del SNU para todo el DPMT y para la Servidumbre de Protección y solicitó al Ayuntamiento de Málaga que justificara las previsiones de ordenación de la ZMT. A tal efecto, se elaboró un informe de la Secretaria General y de la Gerencia de Urbanismo que señalaba sustancialmente que si el suelo urbano dispone de una realidad física urbana, escapa de la esfera voluntarista de la Administración. Tiene 
conceptuación fáctica y reglada, como recoge la jurisprudencia específica. No siendo correcto clasificar como SNU aquellos casos en que el DPMT ha perdido las características que le sirve de protección puesto que por ser dominio público un bien no está adscrito a una determinada clasificación necesariamente. Y en concreto el Suelo de las Barriadas del Palo y Pedregalejo de Málaga, al ser urbano de facto y de iure, había sido clasificado en los anteriores PGOU al vigente como suelo urbano consolidado. La Sentencia Tribunal del Superior de Justicia de Andalucía, de 9 de febrero de 2015, reconoció que aunque era menor la trascendencia que había de reconocerse a esta polémica, como consecuencia de la aprobación de la modificación de la Ley de Costas y la exclusión de determinados núcleos de población del DPMT, como las Barriadas de El Palo y Pedregalejo, estimó correcta la clasificación de SNU de especial protección para el DPMT, aunque incorrecta dicha previsión para la zona de protección y acordó anular el art.55.2 del POTAUM, que imponía la clasificación para todo el suelo incluido en la zona de servidumbre de protección como suelo no urbanizable de especial protección, sin distinguir las singularidades de los núcleos urbanos consolidados.

C) Nulidad de planeamiento por no respeto del carácter de reglado del Suelo No Urbanizable de especial protección.

En cuanto a la nulidad del Planeamiento por la no consideración del régimen reglado del suelo no urbanizable de especial protección, nos sirven de ejemplo la Sentencia del Tribunal Supremo, de 10 de febrero de 2.016, del Algarrobico y la Sentencia de 10 de febrero de 2015, del Tribunal Superior de Justicia de Andalucía sobre el POT de Málaga.

En cuanto a la primera, la del Algarrobico, se aparta conscientemente de otra de la misma Sala S. de 11 de junio 2011, señalando que sobre contradicciones formales en el planeamiento urbanístico y PORN (clasificado como urbanizable en el primero y como no urbanizable en el segundo) prevalecen las características naturales de los terrenos que le hacen ser dignas de protección. Y prevalece el planeamiento medioambiental sobre el urbanístico (STC 102/95 de 26 de junio). Señala, además que "esa contradicción o incoherencia interna solo podía resolverse y clasificarse mediante el examen del problema sustantivo, es decir de la concurrencia o no de características naturales de los terrenos dignas de protección para su inclusión en el PORN, con independencia de las resoluciones judiciales sobre clasificación urbanística de los terrenos, pues esa clasificación debía ceder ante el PORN y no al contrario." Es decir, prevalece la naturaleza reglada del SNU de especial protección.

En sentido contrario, estimando la descalificación como Suelo No Urbanizable de Especial Protección del suelo objeto de la litis, pero manteniendo el carácter reglado del SNU, la STSJA, de 10 de febrero de 2016 anula, en el POTAUM, la clasi- 
ficación como SNU de especial protección, de determinadas fincas, porque es SNU, común y no de especial protección, por carecer de motivación dicha calificación, puesto que estos terrenos carecen de riesgo de inundabilidad, erosión, condicionantes ecológicos ambientales y paisajísticos que merezcan dicha protección. En definitiva, estas dos Sentencias, una del Tribunal Supremo y otra del Tribunal Superior de Justicia de Andalucía, referidas al ámbito de Andalucía, ponen de relieve la plena vigencia del carácter reglado de los Suelos No Urbanizables de Especial Protección, como límite a la potestad discrecional del Planeamiento.

2.3. Motivos nulidad: no corresponde al plan modular la legalización de lo ilegalmente construido. La potestad de ejecutar las Sentencias corresponde exclusivamente al poder judicial

La discrecionalidad inherente a la potestad planificadora no puede modular los efectos de las ilegalidades y fundamentar el nuevo planeamiento en función del carácter aprovechable de lo anterior. Como señala la STS de 27 de octubre de 2015, Rec 313/2.014, no es de recibo la "metodología seguida para la normalización urbanística" que lleva a cabo una valoración conjunta de las diversas infracciones obteniendo los denominados coeficientes de ponderación de la naturaleza de la infracción. Y ello es así porque estamos en una diferente regulación del art. 103.1 de la LRJCA, con respecto a la Ley 39/1956, que señalaba que "la ejecución de las sentencias corresponderá al órgano que hubiese dictado el acto o la disposición objeto del recurso" y en cambio, en la vigente Ley 28/1998, se regula de una manera totalmente contraria, señalando de acuerdo con la $\mathrm{CE}$, que "la potestad de hacer ejecutar las sentencias y demás resoluciones judiciales corresponde exclusivamente a los Juzgados y Tribunales de este orden jurisdiccional."

Por ello, sin alterarse los términos en que la disputa procesal fue planteada y resuelta, no puede pretenderse privar de efectos, posteriormente, al pronunciamiento judicial. Sólo es posible de acuerdo con el principio de congruencia, si concurren elementos que impidan física/jurídicamente la ejecución o la dificulten por circunstancias sobrevenidas impeditivas. En efecto, el legislador ha previsto mecanismos para atender a los supuestos de imposibilidad legal o material de cumplimiento de las sentencias en sus propios términos, como la modificación sobrevenida de la normativa aplicable a la ejecución de que se trate (art.105.2 LJCA). Esto viene avalado constitucionalmente en las Ss.TC 58/1983, 87/1984, 149/1989 y 190/1992 para las que es plenamente constitucional una ejecución de sentencia que por razones atendibles, el fallo condenatorio es sustituido por su equivalente pecuniario u otro tipo de prestación. La STS, Sala 3 ${ }^{\text {a }}$, Sección 5 ${ }^{\mathrm{a}}$, de fecha 3-7-2000, recurso 2061/1995 nos dice que "la existencia de una modificación en aquel (se refiere al planeamiento) puede determinar la posterior adecuación de lo construido al mismo, y originar un supuesto 
de imposibilidad legal de ejecutar la sentencia dictada que ha de ser planteado en trámite de ejecución de sentencia y resuelto por el propio tribunal sancionador".

Si bien no puede perderse de vista la postura jurisprudencial de que las legalizaciones posteriores por la vía de alteración del planeamiento vigente deben encontrar adecuada justificación en consideraciones y criterios de ordenación superiores a la simple voluntad de esa legalización, por todas ellas la STS de 6-6-1.995, recoge que "el ius variandi reconocido a la Administración por la legislación urbanística, se justifica en las exigencias del interés público, y que en la potestad modificatoria de los planes, la Administración no queda vinculada por ordenaciones anteriores, pudiendo establecer nuevas previsiones sobre clasificación y uso de los terrenos. Y efectivamente ello es así, aunque conviene recalcar que tal facultad innovadora de la Administración materializada en la ordenación territorial propia de un Plan de urbanismo, tiene unos límites propios derivados del necesario acatamiento a los estándares urbanísticos previstos en la legislación general sobre el suelo y su ordenación, no menos que a la adecuada satisfacción de las necesidades sociales y del interés público a cuyo servicio ha de estar subordinada la ordenación territorial con ausencia, en todo caso, de cualquier tipo de arbitrariedad en la solución de los problemas urbanísticos dentro de una realidad social determinada".

Por lo que si la modificación del planeamiento se lleva a cabo con la intención de que la sentencia no se ejecute, dicha innovación no conllevará la inejecución de la resolución judicial, (Ss.TS de 30 de noviembre de 1996, de 22 de enero de 1997 y de 25 de junio de 1998).

La STS de 29 de junio de 2002 admitió que se podía dejar sin efecto la demolición acordada, si las obras ejecutadas son habilitadas por las determinaciones de un nuevo planeamiento, habilitando la posibilidad de espera en el cumplimiento de la resolución adoptada en su momento a la aprobación del instrumento de planeamiento, cuando exista posibilidad de su legalización, dado que considera que este caso, el interés público no se ve gravemente afectado por la eventual tardanza en la materialización de la demolición si ello en su día se ratificara como procedente.

Siguiendo esta línea jurisprudencial, el Tribunal Superior de Justicia de Andalucía, Sala de Málaga, había dictado una serie Autos referidos al PGOU de Marbella, como el de 11 de Enero de 2.008, en los que acordaba "aplazar la decisión sobre la procedencia de la demolición hasta el momento de la aprobación definitiva del Plan, que se encuentra tan solo aprobado inicialmente".

Sin embargo la Sentencia del Tribunal Constitucional 22/2009, de 26 de Enero de 2009, ha desautorizado esta línea jurisprudencial señalando que "la decisión judicial de suspender la demolición acordada en Sentencia firme, en expectativa de una futura modificación de la normativa urbanística que, eventualmente, la lega- 
lizará, supone una vulneración del art. 24.1 CE, en su vertiente de derecho a la ejecución de las resoluciones judiciales firmes en sus propios términos" y por ello "no puede admitirse que suponga un supuesto de imposibilidad legal o material la mera expectativa de un futuro cambio normativo, toda vez que ello no implica alteración alguna de los términos en los que la disputa procesal fue planteada y resuelta". La STC 254/2015 reitera la anterior doctrina constitucional señalando que las sentencias firmes de demolición de construcciones ilegales han de ser ejecutadas aun cuando resulten conformes con el planeamiento en tramitación.

En lo referente a la imposibilidad material, la actualidad de la técnica, determina que en puridad nada es imposible de ejecutar materialmente. Habrá de analizarse si esta imposibilidad material, se refiere más bien a actuación desproporcionada, costosa o dificultosa de la "restitutio in natura". La STS de 17 de Diciembre de 2010 consideró de imposibilidad material, en el Municipio de Villaviciosa, la ejecución de la sentencia, por encontrarse la finca ya urbanizada, y ejecutadas las obras. En el mismo sentido la STS 25 de Septiembre de 2.015, considera imposibilidad material la reposición a origen de una urbanización, totalmente ejecutada por el Ayuntamiento de Valladolid. Llegándose incluso, en la Sentencia del Tribunal de Justicia de Castilla León, casada por el TS, a considerar, no sólo que era imposible la "restitutio in natura" de las fincas sino que no tendría ventaja para nadie, ni siquiera para quien la solicitaba, y "que bien podría decirse que al efectuar una solicitud de esa índole parte de la irreversibilidad o prácticamente irreversibilidad de unos hechos consumados para hacer un ejercicio abusivo de su derecho". La Sentencia del TS de 23 de febrero de 2010, acerca de un convenio sobre el nuevo desarrollo de Anoeta (San Sebastián) deja claro, no obstante, el carácter restrictivo de este concepto, que no puede confundirse con una "mera dificultad técnico jurídica de reponer jurídicamente, la situación surgida como consecuencia de la incorrecta licitación, a la situación debida"

Por tanto, si para ejecutar lo juzgado, el órgano judicial adopta una resolución que ha de ser cumplida por un ente público, éste tiene que llevarla a cabo con la necesaria diligencia, sin obstaculizar el cumplimiento de lo acordado, por imponerlo el art.118 CE, y en otro caso, el juez adoptará las medidas necesarias para su ejecución sin dilaciones indebidas. El art.103.2 de La LRJCA centra la obligación del cumplimiento de las Sentencias en las partes procesales. Pero la obligación de colaboración para su ejecución, según el artículo 118 CE y el art.103.3 LRJCA se amplía a todas las personas y entidades públicas y privadas. No obstante, el órgano jurisdiccional valorando las observaciones efectuadas, en relación con la imposibilidad legal o material de ejecución de las Sentencias, decidirá lo procedente en cada caso concreto, por lo que no se puede pretender "aislar o blindar jurídicamente situaciones de infracción judicialmente declaradas al socaire de un nuevo ---e incluso integral y 
completo--- planeamiento frente a la potencialidad jurídica de una resolución de un órgano judicial."

2.4. Motivos Nulidad: No procede exigir nuevas prestaciones que alteren el equilibrio del derecho de propiedad y que sean dependiente de la modulación de la legalización realizada por el planificador

La STS de 27 de octubre de 2.015, Rec. 313/2015, se pronuncia sobre compensaciones económicas dirigidas a financiar la adquisición de terrenos con uso público excluidos de las áreas de regulación pero adscritos a éstas, a efectos de gestión por integrarse en el mismo área de reparto y que se corresponde con exceso de aprovechamiento. El TS rechaza esta regulación porque no es correcto imponer una imputación de cargas y gravámenes individuales, incluso a quienes ya no sean propietarios, cuando lo que realmente se pretende es penalizar antiguas infracciones. No cabe, por ello, considerar legal la obligación supletoria de financiar la parte proporcional que corresponde a los diversos sectores y áreas de reforma interior para la ampliación y reforzamiento redes generales de la ciudad, exteriores a los mismos. Estas dotaciones no son necesarias por razón de la ordenación actual, sino por razón de la previa y anterior ilegalidad del planeamiento precedente: "no son dotaciones del nuevo PGOU sino penalizaciones por incumplimiento anterior PGOU".

Y todo ello, se pretende llevar a cabo, sin respaldo en norma legal alguna, sin tramitar procedimiento individual alguno y sin la garantías previstas para este tipo de exacciones. Aunque por los demandantes se alega que se infringe el art.72.1 RPU, en realidad se infringe el RGU que regula las Unidades de Ejecución deficitarias, donde solo existen deberes para los propietarios y que se produciría la infracción del art.14 6/98 si no se acepta la fuerza de lo factico de "terrenos históricamente consolidados". El Tribunal estima la nulidad pero por incumplimiento del art. 9.2.C) y 16.1 del TRLS08, que se refieren a las obligaciones del propietario, puesto que la ley 6/98 estaba derogada cuando se aprobó el PGOU.

Otra cosa diferente, que si hubiera procedido legalmente, en nuestra opinión, es que con el destino de las multas recogido en el art.197.2 de la LOUA, impuestas al sujeto que hubiese cometido la infracción, se podían mejorar las dotaciones y servicios.

2.5. Motivos Nulidad: No cabe proceder a la alteración por el planificador de mecanismos legales de la responsabilidad por incumplimiento deberes urbanísticos

La planificación urbanística, según el TS no puede alterar lo dispuesto en la Ley en lo relativo a la responsabilidad por los incumplimientos de los deberes urbanísticos. 
Por ello, no cabe atribuir los deberes urbanísticos a anteriores propietarios en contra del art.19 TRLS08. Según el art. 19 del TRLS08, "La transmisión de fincas no modifica la situación del titular respecto de los deberes del propietario conforme a esta Ley y los establecidos por la legislación de la Ordenación Territorial y Urbanística aplicable o exigibles por los actos de ejecución de la misma. El nuevo titular queda subrogado en los derechos y deberes del anterior propietario, así como en las obligaciones por éste asumidos frente a la Administración competente y que hayan sido objeto de inscripción registral, siempre que tales obligaciones se refieran a un posible efecto de mutación jurídico real". (Actual art. 27.1 TRLSRU)

En consecuencia, según el TS, frente a los deberes derivados del incumplimiento de la legalidad urbanística no cabe aducir la condición de adquirente de buena fe, amparado por el acceso de su derecho de propiedad al Registro, ya que conforme al principio de subrogación de los sucesivos adquirentes en el cumplimiento de los deberes, la demolición de lo indebidamente construido no sólo pesa sobre quien realizó la edificación ilegal sino sobre los sucesivos titulares.

Los terceros adquirentes, no están protegidos por el art. 34 de la Ley Hipotecaría, ni exentos de soportar las actuaciones materiales que sean necesarias para ejecutar la Sentencia. Los caminos a los que puede acudir para proteger su derecho son: dejar sin efecto, si aún fuera posible la ejecución de la Sentencia, resolver los contratos por los que adquirieron esta propiedad o obtener del responsable de la infracción urbanística o del incumplidor de los derechos, el resarcimiento de los perjuicios irrogados por la ejecución.(STS 12 de mayo de 2006). No obstante, hay que tener en cuenta que la modificación del art. 51 del TRLS08 por el art. 25.2 del RDL 8/2011, de 1 de julio, ha abierto una nueva vía para el tercero adquirente de buena fe, como es la reclamación a la Administración competente, en el caso que ésta incoe expedientes de disciplina urbanística, en los supuestos previstos en dicho artículo, siempre que la Administración haya incumplido obligación de acordar la practica en el Registro de la propiedad de la anotación preceptiva y se produzcan perjuicios económicos al adquirente de buena fe. Esta misma regulación se contiene actualmente en el art. 28 TRLSRU.

2.6. Otros Motivos Nulidad Planeamiento Urbanístico y Ordenación Territorial por legislación Sectorial

A) La evaluación ambiental estratégica (EAE) no cumple con la Directiva 2001/42/CE ni con la Ley 9/2006 y no contiene evaluación de alternativas razonables aunque sea respetuoso con Decreto Autonómico 292/95 (STS 2180/2014 de 27 de octubre de 2014 FD 12 y 13).

Esta Sentencia entiende que la EAE del PGOU de Marbella infringe la Directiva 2001/42/CE y la Ley 9/2006 (actualmente derogada) porque no contiene la preceptiva identificación, descripción y evaluación de las alternativas razonables 
dirigidas a fijar la Ordenación Urbana del Municipio. El art. 8.1 de la Ley 9/2006, de 28 de abril, (derogada por la Ley 21/2013, de Evaluación Ambiental), decía: "En el informe de sostenibilidad ambiental, el órgano promotor debe identificar, describir y evaluar los posibles efectos significativos sobre el medio ambiente que puedan derivarse de la aplicación del plan o programa, así como unas alternativas razonables, técnica y ambientalmente viables, incluida, entre otras, la alternativa cero, que tengan en cuenta los objetivos y el ámbito territorial de aplicación del plan o programa. A estos efectos, se entenderá por alternativa cero la no realización de dicho plan o programa." Y por ello este informe de sostenibilidad ambiental deberá contener una justificación de las alternativas previstas y los motivos de la elección. La Jurisprudencia del TS (Sentencia de 18 de septiembre de 2013, recurso de casación 5375/2010) pone de relieve que el procedimiento de EAE es independiente de la Evaluación de Impacto Ambiental (EIA) de proyectos, y por ello, aunque la ley 21/2013 de evaluación ambiental unifica la regulación de los dos procedimientos, se cuida muy bien de señalar en su exposición de motivos, que sobre la relación entre la evaluación ambiental estratégica y la de impacto ambiental debe señalarse que, de conformidad con las directivas comunitarias, la primera no excluye a la segunda, de forma que se mantiene la anterior regulación. Igualmente se mantiene el artículo relativo a la relación entre la evaluación de impacto ambiental y la autorización ambiental integrada, ya que esta regulación está contenida en la Ley 16/2002, de 1 de julio, de prevención y control integrado de la contaminación.

Por otra parte, conviene señalar que este informe de sostenibilidad pasa, en la Ley 21/2013, a denominarse: estudio ambiental estratégico, mientras que la memoria ambiental pasa a ser declaración ambiental estratégica a semejanza del estudio de impacto ambiental y declaración de impacto ambiental.

Para el Tribunal, la evaluación ambiental estratégica pierde parte de su finalidad, de anticipar la protección ambiental antes de la toma de decisiones que puedan ser negativas para el medioambiente, cuando "La falta de estudios comparativo de alternativas razonables ambientalmente viables y la denominada alternativa cero vienen determinadas horizontalmente en la normalización de los efectos de las ilegalidades consecuencia de hechos anteriores y que "el documento ambiental que se hubiera podido emitir no podría ,dada la situación preexistente, alcanzar su finalidad".

B) Ausencia del informe de sostenibilidad económica del art. 15.4 del TRLS08 (STS 2180/2014 de 27 de octubre de 2014 FJ 15).- Según el TS, el concepto de sostenibilidad económica, recogido por el legislador estatal en el art. 15.4 del TRLS08 (actual 22.4 del TRLSRU) no debe confundirse con el de viabilidad económica ligado al estudio económico financiero que prevé el coste de ejecución de la actuación y las fuentes de financiación, el análisis de la sostenibilidad económica tiene que justificar la sosteni- 
bilidad de la actuación para las arcas públicas desde que se inicia hasta que termina la responsabilidad para la Administración de las nuevas infraestructuras y servicios necesarios. Así pues, no puede entenderse subsumido en el estudio económico financiero del Plan porque persiguen finalidad distinta y su ausencia provoca la nulidad del PGOU (STS de 30 de marzo de 2015, Recurso 1587/2013)

C) Ausencia de respuesta a las alegaciones en el trámite de información pública y del informe evaluación de impacto por razón de género (STS 6-X-2015: nulidad POT Costa Sol Occidental).- La falta de respuesta a las alegaciones presentadas en el trámite de información pública, deja en papel mojado la participación ciudadana y nos hace retroceder a la Administración decimonónica, alejándonos de una administración electrónica y moderna. Por eso nos parece muy acertada la reiterada jurisprudencia del TS que señala que esta falta de respuesta "equivale a la privación del derecho de audiencia, lo que supone la omisión de un trámite esencial del procedimiento, y a que el exacto cumplimiento de dicho trámite de información pública requiere no solo la mera formalización y recepción de las diversas alegaciones de los interesados, sino su atenta lectura y contestación específica sobre las razones que lleven a la aceptación o rechazo de tales alegaciones y exclusivamente así cabe tener por cumplido el trámite de información pública." (SsTS de 25 de febrero de 2003 (recurso de casación 6876/1999, de 16 de febrero de 2009, recurso de casación 9414/2004 y 15 de marzo de 2012, recurso de casación 6335/2008).

En definitiva, por este motivo de nulidad, el TS por Sentencia de 6 de octubre de 2015, anuló el Plan de Ordenación del Territorio de la Costa del Sol Occidental de la provincia de Málaga. No obstante, el recurso de casación se basaba en un segundo motivo, como es el haber omitido pronunciarse acerca de la impugnación del preceptivo informe del impacto de género en la elaboración del POT impugnado. Aunque el Tribunal en su Fundamento de Derecho Séptimo señala que la estimación del primer motivo de casación, al que nos hemos referido anteriormente, hace innecesario examinar este segundo. No obstante en su FD Sexto, manifestaba que no compartía la tesis de la Administración autonómica demandada, en el sentido que, "como no existen en dicho Plan determinaciones con incidencia en materia de género, resultaba innecesario el informe de evaluación de impacto de género, ya que sería en el informe a emitir donde se debería explicar tal circunstancia.” Y, por ello, según la Sala, esto determinaría la nulidad radical de la norma recurrida, como además ha declarado en otras ocasiones el Tribunal, en supuestos de falta del indicado informe preceptivo de género (Sentencias de fechas de 16 de Abril de 2013, recurso de casación 6470/2011 y 8 de enero de 2.014, recurso de casación 2651/2012).

D) No haber recabado el informe sectorial de telecomunicaciones. (Plan General de Laredo). El Tribunal de Justicia de Cantabria en reciente sentencia de Diciembre de 2016, ha 
anulado el PGOU de Laredo por incumplir el art. 35.2 de la Ley 9/2014, de 9 de Mayo, General de Telecomunicaciones, por no haber recabado el informe preceptivo preceptivo y vinculante del Ministerio de Industria, Energía y Turismo, que tenía que haber sido previo a la aprobación planeamiento urbanístico.

Establece que la consecuencia de la infracción es "la nulidad de pleno derecho en su totalidad" como consecuencia de su carácter de disposición general y de acuerdo con el art. 62 LRJPAG (actual art. 47.2 de la LPAG).

\section{ALGANGE Y EFEGTOS NULIDAD. PROPUESTAS DE SOLU- CIÓN DE LOS EFECTOS DE LA NULIDAD}

\section{Efectos de la nulidad de los planes urbanísticos}

\subsection{Punto de partida: Naturaleza jurídica de Disposición General}

La doctrina jurisprudencial del Tribunal Supremo, prácticamente de manera unánime le atribuye a los Planes urbanísticos la naturaleza de Reglamento. Ello comporta que cualquier tipo de defecto jurídico en su tramitación o contenido, provoca la nulidad de pleno derecho de acuerdo con lo dispuesto en el art. 62.2 de la LRJPAC, para el que serán nulas de pleno derecho las disposiciones administrativas. Tampoco cambia dicha situación con la entrada en vigor de la Ley 39/2015, de 1 de Octubre, puesto que mantiene la misma regulación en su artículo 47.2. Esta nulidad radical de pleno derecho comporta la imposibilidad de subsanación, convalidación o conservación de trámites y la imposibilidad de interposición de recurso de reposición de acuerdo con el art. 107.3 de la LRJPAC que se regula de la misma forma en el art. 112.3 de la Ley 39/2015.

Es indudable por tanto que con lo laborioso y complicado que es el procedimiento de tramitación de un PGOU, su nulidad arrastra unas consecuencias bastantes traumáticas. Y la forma de remediarlo no suele ser fácil. Y aunque existen algunas voces que intentan apuntar hacia una atenuación de esa nulidad radical ${ }^{10} \mathrm{y}$ hay tam-

10 Véase Santamaría Pastor, Juan Alfonso. "Muerte y transformación de la desviación de poder: Sobre las sentencias anulatorias de Planes Urbanísticos". RAP n 195. 2.014. Y "Los Proyectos de Ley del Procedimiento Administrativo Común de las Administraciones Públicas de Régimen Jurídico del Sector Público: Una primera Evaluación". D.A. N 2 Enero-Diciembre 2015. Y Renau Faubell, Fernando. "La nulidad "radiactiva" de los planes urbanísticos por defectos en el procedimiento de aprobación". Noticias Jurídicas $10-3-2016$. 
bién alguna legislación en derecho comparado que abre un camino para solucionar esta cuestión ${ }^{11}$, lo cierto es que en el panorama jurídico español, el carácter de norma jurídica de los Planes Urbanísticos y las consecuencias que su invalidez comporta, se mantiene inalterable.

No obstante, conviene resaltar por su interés sobre lo anterior, la línea jurisprudencial recogida por la STS de 20 de Septiembre de 2012, RJ 2012/9755 (STS de 28 de Febrero de 2001; STS de 26 de Noviembre de 2008/RJ 2009/458), a propósito de la declaración de nulidad del Plan General de Parets del Vallés, por no haberse vuelto a sacar a nueva información pública, antes de la aprobación provisional, por haberse producido modificaciones sustanciales y en contestación a las alegaciones efectuadas sobre la necesariedad de llevar a cabo una nueva tramitación del planeamiento desde el principio. El TS señaló que "no se puede permitir confundir lo que es la nulidad de planeamiento urbanístico por falta de haber agotado la tramitación preceptiva para equipararla a la nulidad de todos los trámites producidos en el procedimiento administrativo de su razón". Deja claro que no era necesaria una nueva aprobación inicial del planeamiento general y que no debe producirse un acuerdo de convalidación, sino que estamos ante nuevas actuaciones, como son la información pública, la nueva aprobación provisional por el Ayuntamiento y la aprobación definitiva "que tienen valor por si mismas"

1.2.-Efectos de la nulidad del Planeamiento.-A) En el Planeamiento y Gestión.- Las Sentencias firmes que anulen un precepto de una disposición general no afectan por si misma a la eficacia de las sentencias o actos administrativos firmes que lo hayan aplicado antes que la anulación alcanzara efectos generales, salvo que como señala el art. 73 de la Ley 29/1998, el precepto suponga la exclusión o reducción de sanciones no ejecutadas completamente. De la misma manera, el art. 64.1 LRJPAC señala que la nulidad o anulabilidad de un acto no implicará la de los sucesivos en el procedimiento que sean independientes del primero.(La misma redacción tiene el art. 49.1 de la LPAC). En el mismo sentido, el art. 40.1 de la Ley 2383/1979 Orgánica del Tribunal Constitucional. Por tanto se produce la subsistencia de los actos firmes dictados en aplicación de la disposición general declarada nula, equiparando, como

11 Véase el nuevo artículo L-600-9 del Código urbanístico francés. La ley francesa Nº 2014-366, de 24 de marzo de 2014, ley para el acceso a la vivienda y un urbanismo renovado, introdujo en el Código Urbanístico francés el nuevo artículo L600-9. En la redacción vigente, establecida por la Ordenanza $\mathrm{N}^{\circ}$ 2015-1174, de 23 de septiembre de 2015, posibilita al juez administrativo que conoce un recurso interpuesto contra un plan urbanístico, en el caso que el motivo alegado sea un vicio de procedimiento, puede subsanar ese defecto. Durante este plazo de subsanación el plan recurrido sigue en vigor. Subsanado por la Administración el defecto de procedimiento, el Tribunal resolverá el recurso. 
señala Sanchez Goyanes"12, "la anulación o la derogación, en que los efectos son "ex nunc" y no "ex tunc", si bien sólo respecto de los actos firmes, permaneciendo en cuanto a los no firmes la posibilidad de impugnarlos en función del ordenamiento jurídico aplicable, una vez declarada nula la disposición general”.

La nulidad del Plan General de Ordenación Urbanística provoca la nulidad del Planeamiento secundario y de los actos de Ejecución y Gestión del propio PGOU. En efecto la STS de 28 de septiembre de 2012, recurso de casación 1009/2011 señala que "los efectos propios de la nulidad plena impiden igualmente que el ordenamiento derivado, planes parciales y de sectorización, puedan tener cobertura en las concretas normas declaradas nulas, como venimos señalando de modo profuso y uniforme en el ámbito urbanístico".

Igualmente como señala la STS de 25 de Septiembre de 2015, recurso 3.003/2013, es doctrina del TS (Ss 19 de Mayo y 6 de Junio de 1992, 11 de Noviembre de 1993 y 19 de Diciembre de 2003, entre otros), que "la anulación de los actos administrativos por los que se aprueba el planeamiento urbanístico del que trae causa la expropiación deja sin efecto ni valor alguno las declaraciones de utilidad pública y necesidad de ocupación desapareciendo la causa expropiandi y acarreando todo ello la nulidad del procedimiento expropiatorio, incluido la determinación del justiprecio".

B) En las Licencias.- Otra cuestión es lo referente a las licencias. En efecto como señala Escribano Testaut ${ }^{13}$ no ha sido exactamente la misma jurisprudencia, la recaída sobre los puros actos de aplicación del planeamiento, como son las licencias, que la recaída sobre el planeamiento.

En efecto como ya señalaba el TS en Sentencia de 25 de marzo de 1991 "la nulidad de un Plan de Ordenación no provoca siempre la de las licencias otorgadas a su amparo" sino que quedan "subsistiendo en principio las que sean firmes por aplicación de lo dispuesto en la Ley de Procedimiento Administrativo, dado el carácter normativo de los Planes y la condición de aplicación de ellos de las licencias urbanísticas", aunque otra es la posición de las licencias no firmes, que quedan "solo ante el

12 Sánchez Goyanes, Enrique. "Extinción jurídica de un plan y supervivencia de sus actos derivados: uniformidad en la diversidad jurisprudencial". Práctica Urbanística $\mathrm{N}^{\circ} 106$, Seccion Estudios, Julio 2011. Pag 16 Ed. La Ley.

13 Escribano Testaut, Pedro. "Las causas y los efectos directos y colaterales de la declaración de nulidad del PGOU de Ourense. Práctica Urbanística No 121 Marzo-Abril 2013. Editorial La Ley. 
resto de la normativa urbanística vigente, que podrá decidir si las mismas son nulas de pleno derecho, anulables o incluso válidas".

¿Y qué ocurre por tanto con las licencias declaradas ilegales por nulidad del Planeamiento urbanístico? Como señala la Sentencia del TS de 27 de octubre de 2015, recurso 313/2014: "Cuando media una sentencia anulatoria de una licencia por disconformidad con el planeamiento la nueva ordenación no deja sin efecto aquella sino que acaso pudiera constituir un supuesto de imposibilidad legal de su ejecución.” De acuerdo con el art. 5 del Reglamento de Disciplina Urbanística de Andalucía cuando la ejecución de la Sentencia sea imposible legal o materialmente, se llevará a efecto su cumplimiento por equivalencia mediante la indemnización correspondiente. El apartado 2 del art. 53, señala que en ese caso quedarán los actos de uso del suelo y en particular las obras, instalaciones y construcciones y edificaciones, en situación de asimilación a la de fuera de ordenación.

En efecto, como hemos dicho anteriormente, si concurren causa de imposibilidad material o legal, el órgano obligado a su cumplimiento lo comunicará al Tribunal para que adopte las medidas para su mayor efectividad ejecutoria o en su caso la indemnización que proceda por la parte que no pueda ser objeto de cumplimiento pleno de acuerdo con el (art.105.2 ley 29/1998).

\section{Propuestas para mitigar las consecuencias y efectos de la nulidad del Planeamiento Urbanistico y Ordenación del Territorio en Andalucía}

2.1. Medidas en relación con el Planeamiento.- A) Adaptación Parcial Planeamiento vigente a la LOUA de acuerdo con el Decreto 11/2008, de 22 de Enero

La anulación de un PGOU, determinará, como regla general, la reviviscencia del anterior planeamiento vigente, al plan anulado, lo que provocará que se ponga nuevamente en vigor un PGOU que, en Andalucía, no estará como regla general adaptado a la LOUA y que al haber transcurrido cuatro años de la entrada en vigor de la LOUA, "no podrán aprobarse modificaciones del planeamiento general que afecten a las determinaciones propias de la ordenación estructural, a dotaciones o a equipamientos cuando dicho instrumento de planeamiento no haya sido adaptado a la presente Ley, al menos de forma parcial" (Disposición transitoria segunda 2. párr. $2^{\circ}$ de la LOUA). Ésto entre otras cosas impedirá una reclasificación del suelo que dé lugar a operaciones urbanísticas no contempladas en el PGOU, no adaptado y en vigor. Por ello, la primera medida a adoptar en Andalucía para mitigar el extraordinario impacto que supone la nulidad de un PGOU en Andalucía, debiera ser la de acudir a la adaptación a la LOUA del PGOU que revive, tras la anulación de un Plan General de Ordenación Urbanística, al procedimiento de adaptación parcial 
previsto en El Decreto 11/2008, cuya competencia de aprobación corresponde al Ayuntamiento. Este procedimiento es compatible con la revisión del mismo.

En el contenido y alcance de este documento destaca en primer lugar que, adecua las determinaciones del PGOU vigente a la LOUA, recogiendo, entre otras, las siguientes determinaciones:

- clasificación de la totalidad del suelo del municipio, delimitando las superficies adscritas a cada clase y categorías de suelo, pero no podrá:

- clasificar nuevos suelos urbanos, salvo los ajustes en la clasificación de suelo

- clasificar nuevos suelos como urbanizables.

- alterar la regulación del suelo no urbanizable, salvo que haya sobrevenido la calificación de especial protección.

Y lo que tiene más transcendencia, en segundo lugar, es que según lo que dice su Disposición adicional primera 2, una vez aprobada la adaptación parcial, los municipios podrán formular modificaciones que afecten a la ordenación estructural, a dotaciones o a equipamientos. Y que por tanto será posible que se puedan llevar a cabo modificaciones del planeamiento de carácter estructural a partir de la aprobación de la adaptación.

B) Subsiguientes modificaciones.- Una vez llevada a cabo la adaptación parcial del planeamiento anteriormente señalado, lo aconsejado es, que las operaciones de más interés para la ciudad y que cuenten con la garantía de su financiación podrán llevarse a cabo mediante modificaciones puntuales siempre que no excedan lo dispuesto en el art. 37.2 de la LOUA, que señala que se considera que una innovación trasciende del ámbito de la actuación, conllevando la revisión del planeamiento a los efectos de la sostenibilidad, cuando ésta determine por sí misma o en unión de las aprobadas definitivamente en los cuatro años anteriores a la fecha de su aprobación inicial, un incremento superior al veinticinco por ciento de la población del municipio o de la totalidad de la superficie de los suelos clasificados como urbanos, descontando de dicho computo los suelos urbanos no consolidados que se constituyan como vacíos relevantes.

C) Revisión parcial o general.- En este orden de actuaciones recomendadas para poner en marcha, lo más pronto posible, la actividad urbanística de la ciudad que sufre la anulación de un PGOU, en el caso de operaciones de mayor alcance sería el de acudir a revisiones parciales. Como señala el art. 37 de la LOUA "la revisión puede ser total o parcial según su ámbito o alcance. La revisión puede ser parcial cuando justificadamente se circunscriba a una parte, bien del territorio ordenado por el instrumento de planeamiento objeto de la misma, bien de sus determinaciones que forman un conjunto homogéneo, o de ambas a la vez. Y en última instancia para 
una innovación integral estaría la revisión general. Ahora bien, habrá de tenerse en cuenta en la tramitación de la revisión parcial o general, los límites del planeamiento en cuanto al suelo de carácter reglado: Urbano y SNUEP, así como lo que hemos señalado en relación los informes sectoriales y los motivos de nulidad analizados, para no incurrir nuevamente en nulidad.

2.2. Medidas en relación con las licencias ilegales.-Como hemos dicho, las licencias ilegales otorgadas en base a un PGOU anulados que sean firmes, quedarán subsistentes. En resto de los casos habría que distinguir las siguientes situaciones:

A) Sin procedimiento judicial: Sólo administrativo.- Habría que diferenciar si existe o no una orden de demolición acordada. En el caso que no exista la orden de demolición acordada, y no hayan caducado las medidas de protección de la legalidad, es inexcusable el ejercicio de la potestad de protección de la legalidad, salvo que exista imposibilidad legal o material de su ejecución. Si se hubiera producido la caducidad de las medidas de protección de la legalidad, sería posible, según proceda, la aplicación del régimen de fuera de ordenación o el de asimilada al de fuera de ordenación. (Art.3 1.B a) y b) del Decreto 2/2012, de 10 de Enero de Andalucía).

En segundo lugar, cuando exista una orden de demolición acordada por órgano administrativo pero no judicial, si no ha prescrito esta orden de demolición, debe ejecutarse inexcusablemente ${ }^{14}$, salvo que existe una imposibilidad legal o material y asi se acredite en un expediente individualizado, por el órgano administrativo competente, "sin perjuicio de la potestad jurisdiccional de hacer ejecutar lo juzgado, en los casos que haya recaído resolución judicial firme. Art.51.1 RDUA).

La legislación urbanística no ha regulado la prescripción de esta orden de demolición y se aplicaba, mayoritariamente el plazo general de prescripción de 15 años del art.1964 CG a contar desde la firmeza (Sentencias Tribunal Supremo 11 julio 1985,5 de junio 1987,17 de febrero 2000. De manera minoritaria el Tribunal Superior de Justicia de Madrid señalaba aplicable el plazo quinquenal previsto para la demanda ejecutiva del art. 518 LEC. La STS 29, de diciembre 2.010, desestimó la anterior doctrina jurisprudencial del TSJM. Actualmente, la DT Quinta de la ley 42/2015 ha modificado el plazo de prescripción del Gc, reduciéndolo a 5 años. Y para el régimen transitorio se remite al art. 1939 Cc.

B) Con procedimiento judicial firme.- Deberá, como hemos señalado, cumplirse la ejecución de la sentencia en sus propios términos, salvo en los que así se determine, en el caso de imposibilidad legal o material, por el propio poder judicial. O bien haya

14 Véase Gutiérrez Colomina, Venancio. "La protección de la legalidad en el régimen urbanístico de Andalucía”. Práctica Urbanística. N¹12. El Consultor. 
prescrito el plazo de ejecución de la orden de demolición, referida en el apartado anterior.

Ha habido varios intentos en la legislación autonómica para alterar en alguna medida la competencia del poder judicial o las condiciones a que debe someterse la ejecución de sentencias que lleven aparejado el derribo de edificaciones ilegales. Así el art.65 bis.1 de la Ley cántabra 2/2001, añadido por la Ley 4/2013 de 20 de junio, estableció la posibilidad que el órgano municipal competente suspendiera provisionalmente las ordenes de demolición administrativas o judiciales, previa comprobación que resultaban conformes con el nuevo planeamiento municipal en tramitación, La STC 254/2015 ha declarado nulo e inconstitucional el inciso "judicial", dejando subsistente exclusivamente las administrativas. A su vez la Disposición adicional sexta de la Ley 8/2012 gallega reconoció, a los titulares de las viviendas construidas al amparo de un título anulado, el derecho a residir en el inmueble mientras no se determinase por la Administración competente, a través del correspondiente procedimiento de responsabilidad patrimonial, el alcance de la indemnización que pudiera corresponderles, al haber establecido que el acto administrativo o sentencia firme que determinara la anulación del título e implicara la reposición de la legalidad urbanística y la demolición de lo construido, llevaría consigo, como efecto legal necesario la apertura de oficio del procedimiento de responsabilidad patrimonial. La STC 82/2014 de 28 de mayo declara nulo el inciso "o Sentencia" del apartado 2 de la DA sexta de la ley 8/2012, por lo que a partir de ésta, la DA sexta sólo regulará el procedimiento a seguir cuando la anulación del título, se produzca mediante acto administrativo firme y no por sentencia, puesto que aquel no afecta al ejercicio de la potestad jurisdiccional, ni a la competencia reservada al Estado en materia de legislación procesal (arts. 117.3 y 149.1.6 CE).

En el ámbito de la legislación estatal se han producido dos modificaciones que afectan decididamente a esta cuestión y que aumentan los problemas de ejecución de las sentencias urbanísticas sobre la demolición de edificaciones ilegales ${ }^{15}$. En primer lugar la del Código Penal, llevada a cabo, adicionando por el número ciento setenta y uno del artículo único de la L.O. 1/2015, un apartado 3 al art.319 que dice;

"3. En cualquier caso, los jueces o tribunales, motivadamente, podrán ordenar, a cargo del autor del hecho, la demolición de la obra y la reposición a su estado originario de la realidad física alterada, sin perjuicio de las indemnizaciones debidas a terceros de buena fe, y valorando las circunstancias, y oída la Administración competente, condicionarán temporalmente la demolición a la constitución de garantías que aseguren el pago de aquéllas. En todo caso se dispondrá el decomiso

15 Alonso Ibáñez, María Rosario "La imposibilidad de ejecución de sentencias de demolición de edificaciones. Medidas Legales. Obra colectiva "Por el Derecho y la Libertad. Libro Homenaje al Prof. Juan Alfonso Santamaría Pastor". Iustel, Madrid 2014. 
de las ganancias provenientes del delito cualesquiera que sean las transformaciones que hubieren podido experimentar."

En relación con esta innovación del Código Penal conviene destacar que la suspensión temporal de la demolición para la constitución de garantías para hacer frente a las indemnizaciones a terceros de buena fe, encomendada por el poder legislativo al judicial, tiene carácter facultativo y no imperativo. Y además, el Juez deberá hacerlo valorando las circunstancias y oída la Administración competente. Al no ser de aplicación automática, ni de carácter imperativo, en principio no parece censurable. Cuestión diferente es la llevada a cabo posteriormente, para adaptarse a esta modificación del Código Penal, por la Ley Orgánica del Poder Judicial, introduciendo el apartado 3 del art. 108 en la LJCA, que señala lo siguiente:

“3. El Juez o Tribunal, en los casos en que, además de declarar contraria a la normativa la construcción de un inmueble, ordene motivadamente la demolición del mismo y la reposición a su estado originario de la realidad física alterada, exigirá, como condición previa a la demolición, y salvo que una situación de peligro inminente lo impidiera, la prestación de garantías suficientes para responder del pago de las indemnizaciones debidas a terceros de buena fe".

En este caso, el carácter imperativo para el juez de la exigencia de garantías suficiente para hacer frente al pago de las indemnizaciones debidas a terceros de buena fe, plantea una cierta incertidumbre de constitucionalidad del precepto y su contenido deja irresueltas, entre otras cuestiones, la cuantía de las garantías, el plazo de suspensión y el sujeto a quien le corresponde hacer frente a las garantías y cuya determinación, obviamente, complicará y alargará el procedimiento de ejecución. 